\title{
Substance P Modulates NMDA Responses and Causes Long-Term Protein Synthesis-Dependent Modulation of the Lamprey Locomotor Network
}

\author{
David Parker, Weiqi Zhang, and Sten Grillner \\ The Nobel Institute for Neurophysiology, Department of Neuroscience, Karolinska Institute, S 17177, Stockholm, Sweden
}

Tachykinin immunoreactivity is found in a ventromedial spinal plexus in the lamprey. Neurons in this plexus project bilaterally and are thus in a position to modulate locomotor networks on both sides of the spinal cord. We have examined the effects of the tachykinin substance $P$ on NMDA-evoked locomotor activity. Brief (10 min) application of tachykinin neuropeptides results in a prolonged concentration-dependent ( $>24 \mathrm{hr}$ ) modulation of locomotor activity, shown by the increased burst frequency and more regular burst activity. These effects are blocked by the tachykinin antagonist spantide II.

There are at least two phases to the burst frequency modulation. An initial phase $(\sim 2 \mathrm{hr})$ is associated with the protein kinase C-dependent potentiation of cellular responses to NMDA. The long-lasting phase ( $>2 \mathrm{hr}$ ) appears to be protein synthesis-dependent, with protein synthesis inhibitors causing the increased burst frequency to recover after washing for 2-3 $\mathrm{hr}$. The modulation of the burst regularity is caused by a separate effect of tachykinins, because unlike the burst frequency modulation it does not require the modulation of NMDA receptors for its induction and is blocked by $\mathrm{H} 8$, an inhibitor of CAMPand cGMP-dependent protein kinases. The effects of substance $\mathrm{P}$ were mimicked by the dopamine D2 receptor antagonist eticlopride. The effects of eticlopride were blocked by the tachykinin antagonist spantide II, suggesting that eticlopride may endogenously release tachykinins. Because locomotor activity in vitro corresponds to that during swimming in intact animals, we suggest that endogenously released tachykinins will result in prolonged modulation of locomotor behavior.

Key words: neuropeptide; substance P; dopamine; neuromodulation; locomotor network; protein synthesis
Neuromodulation and synaptic plasticity can alter the output of neural circuits, thus affecting any behaviors that these circuits control. Although the analysis of neuromodulation and synaptic plasticity at any level is of value, an integrative approach in which effects are studied directly at several levels is ultimately more informative (Harris-Warrick et al., 1992; Byrne and Kandel, 1996). This type of analysis, however, is difficult to perform in most vertebrate systems.

In the lamprey, a lower vertebrate, the locomotor network has been characterized by making single or paired intracellular recordings from identified network neurons (Grillner et al., 1995; Buchanan, 1996), thus allowing the types of neurons, their membrane properties, and their transmitter receptors to be identified (Grillner et al., 1995; Buchanan, 1996). The spinal cord contains a number of different peptidergic and aminergic modulators (Wallén et al., 1989; Parker and Grillner, 1996; El Manira et al., 1997). These can target particular ion channels, resulting in specific changes in locomotor activity (Brodin and Grillner, 1990; Grillner et al., 1994). The aim of this study is to characterize the effects of tachykinins on the lamprey locomotor network and its component neurons.

In the lamprey, as in higher vertebrates, tachykinin immunoreactivity is found in the dorsal root, dorsal column, and dorsal horn

\footnotetext{
Received Feb. 3, 1998; revised March 30, 1998; accepted April 7, 1998.

This work was supported by grants from the Wellcome Trust and Swedish Brain Foundation (D.P.), the Karolinska Institutet Fonder, the Swedish Medical Research Council (3026) (S.G.), and the Swiss National Science Foundation, the Wenner Gren Foundation, and the Oetliker Stiftung (W.Z.).

Correspondence should be addressed to D. Parker, Nobel Institute for Neurophysiology, Department of Neuroscience, Karolinska Institute, S 17177, Stockholm, Sweden.

Copyright (ㄷ) 1998 Society for Neuroscience $\quad 0270-6474 / 98 / 184800-14 \$ 05.00 / 0$
}

(Van Dongen et al., 1985, 1986) and in a ventromedial spinal cord plexus in which motor neurons and network interneurons distribute their medial dendrites (see Fig. $1 A$ ). The structural characterization of lamprey tachykinins has shown that the functionally important C-terminal sequence has been conserved during vertebrate evolution (Waugh et al., 1995). The effects of tachykinins have been examined extensively on sensory processing in higher vertebrates (Levine et al., 1993) but to a much lesser extent on motor activity (White, 1985; Barthe and Clarac, 1997). Tachykinins act on sensory inputs in the lamprey via several different protein kinase $\mathrm{C}$-mediated cellular mechanisms. Tachykinins depolarize and increase the excitability of primary afferents and sensory interneurons, and presynaptically potentiate and inhibit glutamatergic and glycinergic synaptic inputs, respectively (Parker and Grillner, 1996; Parker et al., 1997). The ventromedial plexus contains cells that are immunoreactive to tachykinins, 5-hydroxytryptamine (5-HT), and dopamine (DA/5-HT/TK plexus) (see Fig. 1A) (Van Dongen et al., 1985, 1986; Schotland et al., 1995). A proportion of the tachykinin-containing fibers and cell bodies are immunoreactive for 5-HT (Van Dongen et al., 1985, 1986). Neurons in the DA/5-HT/TK plexus project bilaterally and thus are in a position to influence locomotor networks on both sides of the spinal cord. 5-HT and dopamine reduce the frequency of locomotor bursts (Harris-Warrick and Cohen, 1985; McPherson and Kemnitz, 1994; Schotland et al., 1995, 1996), although low concentrations of dopamine increase the burst frequency (McPherson and Kemnitz, 1994). Dopamine and 5-HT have complementary cellular effects on calcium and calciumdependent potassium channels, respectively (Wallén et al., 1989; Schotland et al., 1995). In this paper, we show that tachykinins cause a concentration-dependent, long-lasting modulation of lo- 
comotor activity. This is initially caused by a protein kinase $\mathrm{C}$-mediated potentiation of cellular responses to NMDA, followed by a longer-lasting phase $(>2 \mathrm{hr})$ that is protein synthesis-dependent.

\section{MATERIALS AND METHODS}

Adult lampreys (Lampetra fluviatilis and Petromyzon marinus) were anesthetized with tricaine methane sulfonate (MS-222; Sandoz, Basel, Switzerland). Seasonal availability necessitated the use of these two species. The two species showed the same responses to substance P. In experiments examining network activity, the spinal cord and notochord (10-15 segments) were isolated and placed in a Sylgard (Sikema, Stockholm, Sweden)-lined chamber, where the connective tissue and meninx primitiva were removed from the dorsal surface of the cord. The spinal cord was superfused with Ringer's solution containing (in $\mathrm{mM}$ ): $138 \mathrm{NaCl}, 2.1$ $\mathrm{KCl}, 1.8 \mathrm{CaCl}_{2}, 1.2 \mathrm{MgCl}_{2}$, 4 glucose, 2 HEPES, and 0.5 L-glutamine, which was bubbled with $\mathrm{O}_{2}$ and the $\mathrm{pH}$ adjusted to 7.4. Nominally magnesium free Ringer's solution consisted of (in mM): $140.4 \mathrm{NaCl}, 2.1$ $\mathrm{KCl}, 1.8 \mathrm{CaCl}_{2}, 4$ glucose, 2 HEPES, and $0.5 \mathrm{~L}$-glutamine. The experimental chamber was kept at a temperature of $8-12^{\circ} \mathrm{C}$.

Locomotor activity was elicited by bath-applying NMDA (30-200 $\mu \mathrm{M})$ or kainate $(5-10 \mu \mathrm{M})$ (Brodin et al., 1985). Activity was recorded by placing suction electrodes on ventral roots on both sides of the body. The cycle duration was defined as the time between the onset of two successive ventral root bursts on the same side. The coefficient of variation (CV) was calculated as the SD of the cycle duration divided by the mean cycle duration. The cycle duration was defined as the time interval between the onset of successive bursts in a single ventral root. Drugs were added only after the pattern of activity had been constant for at least $1 \mathrm{hr}$. Kainate activity was more difficult to elicit than NMDA activity, which required up to $2 \mathrm{hr}$ before significant activity appeared and up to an additional $2 \mathrm{hr}$ before the activity became stable.

Intracellular recordings were made from identified motor neurons and network interneurons using thin-walled glass electrodes filled with $3 \mathrm{M}$ potassium acetate and with resistances of 40-60 M $\Omega$. The spinal cord was usually isolated from the notochord for intracellular experiments. The connective tissue and meninx primitiva were removed from the dorsal and ventral surfaces of the spinal cord, which was then placed ventral side up in the recording chamber. A plastic net, secured by pinning it to the Sylgard, was placed over the cord to keep it stable. Motor neurons were identified by orthodromic spikes recorded in adjacent ventral roots after current injection into the soma, whereas crossed caudal (CC) interneurons were identified by recording orthodromic spikes with a suction electrode placed on the contralateral caudal region of the spinal cord at least 10 segments from the impaled neuron (Buchanan, 1993). Axon Instruments software (pClamp, Axotape, Axon Instruments, Foster City, CA) was used for data acquisition and analysis on a 486 PC-computer equipped with an A/D interface (Digidata 1200, Axon Instruments).

Cellular responses to excitatory amino acids were examined by pressure-applying NMDA and AMPA onto the surface of the spinal cord above the impaled neuron. Because the spinal cord is thin $(200 \mu \mathrm{m})$, drugs applied in this way readily gain access to somata in the spinal cord. These experiments were performed in tetrodotoxin (TTX; $1.5 \mu \mathrm{M}$ ) to block indirect effects attributable to the activation of nearby neurons. Pressure-pulse durations of 10-100 msec were used in different experiments to give clear, consistent responses. NMDA and AMPA responses were evoked at intervals of 1-2 min. Application at this frequency did not in itself cause any changes in NMDA or AMPA responses (data not shown).

Drugs were added directly to the Ringer's solution and applied to the bath for $10 \mathrm{~min}$, unless stated otherwise. Stock solutions of phorbol 12,13 dibutyrate, 4- $\alpha$ phorbol 12,13 dibutyrate, chelerythrine (RBI, Natick, MA), BAPTA-AM, and EGTA-AM (Molecular Probes, Leiden, The Netherlands) were made by dissolving them in DMSO. In each case the final concentration of DMSO in the Ringer's solution was $0.1 \%$. This concentration of DMSO did not affect the locomotor frequency or the effects of eticlopride or substance P (data not shown). Spinal cords were preincubated in the translational protein synthesis inhibitors anisomycin, puromycin, and cyclohexamide (Sigma, Stockholm, Sweden) for 1-4 hr, in EGTA-AM for $2 \mathrm{hr}$, and in chelerythrine, H8, or spantide for $1 \mathrm{hr}$ before substance $\mathrm{P}$ application. A second piece of spinal cord, taken from the same animal, was used as a control in each of these experiments.

Unless stated otherwise, statistical significance was examined using two-tailed paired $t$ tests. The numbers in the text refer to the number of cords used, with no more than two pieces of cord being taken from the same animal.

\section{RESULTS}

\section{Tachykinin effects on locomotor burst frequency}

Bath application of the tachykinin substance $\mathrm{P}$ for $10 \mathrm{~min}$ resulted in a concentration-dependent increase in the frequency of NMDA-elicited ventral root bursts and of the excitability of network neurons (Fig. $1 B, C)(10 \mathrm{~nm}, p>0.05 ; 100 \mathrm{~nm}, p<0.05$; $1 \mu \mathrm{M}, p<0.01)$. The recovery of this effect after washout was also concentration-dependent (Fig. 1C). With $10 \mathrm{~nm}$ substance $\mathrm{P}$, the frequency usually recovered to control after washing for $30 \mathrm{~min}$ to $1 \mathrm{hr}(n=8)$. With $100 \mathrm{nM}$ substance $\mathrm{P}$, the frequency initially increased slightly after washing for $1 \mathrm{hr}$ and recovered after washing for $\sim 4-5 \mathrm{hr}(n=8)$. With $1 \mu \mathrm{M}$ substance P, however, the frequency increased after washing for $1 \mathrm{hr}$ and did not recover to control after washing for $10 \mathrm{hr}(n=63)$ (Fig. $1 C)$. Recovery was never seen in preparations that were examined $24 \mathrm{hr}$ after substance $\mathrm{P}$ application ( $n=5$ of 5 ). The effect of substance $\mathrm{P}$ on the burst frequency occurred across the range of NMDA concentrations used (50-200 $\mu \mathrm{M}$; data not shown), although the percentage increase in frequency was greatest when the control frequency was low (Fig. 1D).

Although $1 \mu \mathrm{M}$ substance $\mathrm{P}$ consistently increased the burst frequency ( $n=60$ of 63 ), the initial effects after 10 min application could be variable. The increased burst frequency developed immediately after the application of substance $\mathrm{P}$ in 23 preparations. In 18 preparations the locomotor activity was transiently disrupted, with this effect not lasting for more than 5-10 min. In the remaining preparations $(n=19)$, the burst frequency was transiently reduced, and the increased burst frequency usually developed within $30 \mathrm{~min}$ of substance $\mathrm{P}$ application (data not shown).

\section{Tachykinin effects on the burst regularity}

In addition to potentiating the frequency of locomotor bursts, substance $\mathrm{P}$ also had a concentration-dependent effect on the burst regularity (Fig. $2 A, B$ ). This was shown quantitatively by a reduction of the $\mathrm{CV}$ (SD of cycle duration/mean cycle duration) (Fig. 2A). This effect was also concentration-dependent $(10 \mathrm{nM}$, $p>0.05 ; 100 \mathrm{nM}, p>0.05 ; 1 \mu \mathrm{M}, p<0.05)$ and with $1 \mu \mathrm{M}$ was again long lasting (see Fig. 10Aii). With lower concentrations of substance $\mathrm{P}$, the reduction of the $\mathrm{CV}$ occurred only when the initial value was high, i.e., when the activity was irregular (Fig. 2C) $\left(10 \mathrm{~nm} r^{2}=0.52 ; 100 \mathrm{~nm} r^{2}=0.81\right)$, and with a low initial CV, 10 or $100 \mathrm{~nm}$ substance $\mathrm{P}$ could result in a nonsignificant increase in the $\mathrm{CV}$ (Fig. $2 C)(p>0.05)$. With $1 \mu \mathrm{M}$ substance $\mathrm{P}$, however, the $\mathrm{CV}$ was reduced regardless of its initial level $\left(r^{2}=0.08\right)$ (Fig. $2 C)$. The $\mathrm{CV}$ is not related to the burst frequency (Fig. $2 D)(n=$ $\left.48 ; r^{2}=0.01\right)$, i.e., faster activity is not necessarily more regular. This suggests that the modulation of the CV is not simply caused by the increased burst frequency but by a separate effect of substance $\mathrm{P}$ on the locomotor network. The effects of substance $\mathrm{P}$ on burst frequency and $\mathrm{CV}$ were mimicked by the mammalian tachykinin neurokinin A $(n=3)$, the amphibian tachykinin physalaemin $(n=3)$, and the molluscan tachykinin eledoisin $(n=3$; data not shown).

\section{Involvement of NMDA receptor activation or network activity in the burst frequency modulation}

Experiments examining the dependence of the network modulation on the presence of NMDA, and thus network activity, were 
A

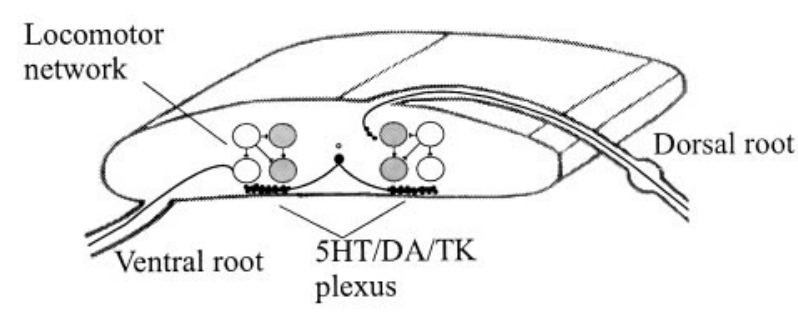

B

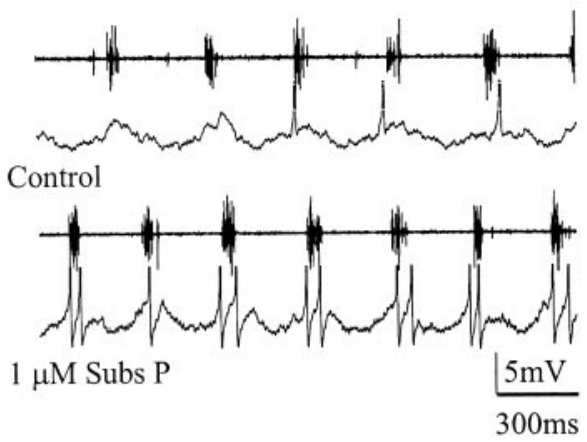

D
C

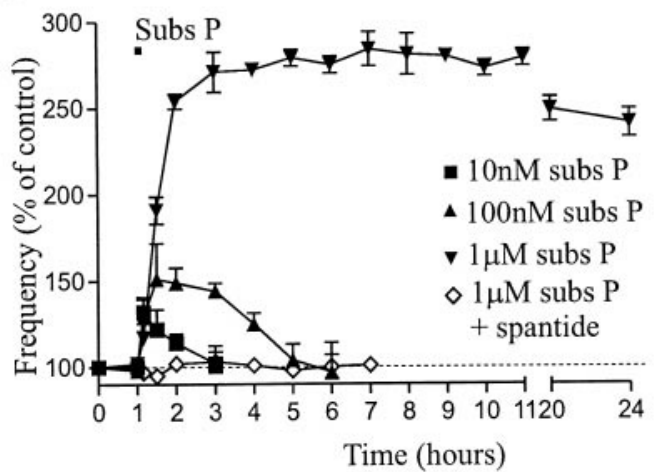

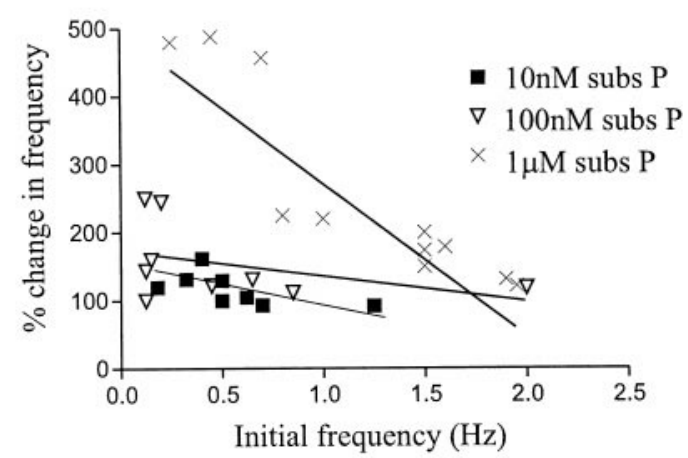

Figure 1. A, Schematic diagram showing the location of potential tachykinin inputs to locomotor networks in the lamprey spinal cord. B, Bath application of substance $\mathrm{P}(1 \mu \mathrm{M})$ for $10 \mathrm{~min}$ increased the frequency of NMDA-induced ventral root bursts and increased the activity of an unidentified locomotor network neuron. $C$, The increase in burst frequency by substance $\mathrm{P}$ was concentration-dependent, as was the recovery on washing $(10 \mathrm{~nm}, n=$ $8 ; 100 \mathrm{nM}, n=8 ; 1 \mu \mathrm{M}, n=63)$. $D$, The percentage substance P-mediated increase in the frequency of locomotor bursts was greatest when the initial frequency was low. The bar indicates the time and duration of substance $\mathrm{P}$ application.

also performed. In these experiments, control NMDA-elicited activity was recorded, and then the NMDA was washed out. Substance $\mathrm{P}(1 \mu \mathrm{M})$ was applied $30 \mathrm{~min}$ after all network activity had stopped. NMDA was then reapplied to the bath at various times after the washout of substance $\mathrm{P}$ had started (Fig. 3A). Significant potentiation $(p<0.01)$ of the burst frequency still occurred in cords in which substance $\mathrm{P}$ was applied in the absence of NMDA, and thus network activity, providing that NMDA was reintroduced to the bath not later than $1 \mathrm{hr}$ after substance $\mathrm{P}$ application (Fig. $3 A$ ). Reapplication of NMDA $2 \mathrm{hr}$ after the start of substance $\mathrm{P}$ washout resulted in the failure of any significant potentiation to develop $(p>0.1)$. The potentiation of the burst frequency was not significantly different in experiments when NMDA was present throughout, or when it was reapplied 20 or 60 min after substance $\mathrm{P}(p>0.1$; one-way ANOVA), but was significantly different when NMDA was reapplied after $2 \mathrm{hr}(p<$ 0.05; one-way ANOVA). This suggests that the modulation of the burst frequency does not require the presence of NMDA or network activity during substance $\mathrm{P}$ application, but that NMDA or network activity, or both, are required within $\sim 1$ hr of substance $\mathrm{P}$ application. In contrast to the effect on the burst frequency, the reduction of the $\mathrm{CV}$ was blocked when substance $\mathrm{P}$ was applied in the absence of NMDA and network activity, even if NMDA was reapplied to the bath within 20 min after the start of substance $\mathrm{P}$ washout (Fig. $3 B)(n=12 ; p>0.1)$. This suggests that the modulation of the $\mathrm{CV}$ requires network activity or NMDA or both to be present when substance $\mathrm{P}$ is applied, thus suggesting that different mechanisms underlie the two effects on the locomotor network.

\section{Effects of tachykinin antagonists}

The specific NK-1 receptor antagonist WIN 51,708 (4 $\mu \mathrm{M})$, which fails to antagonize the effects of substance $\mathrm{P}$ on mechanosensory neurons in the lamprey (Parker et al., 1997), also failed to block the network effects of substance $\mathrm{P}(n=3$; data not shown). However, preincubation of the spinal cord with the general tachykinin antagonist spantide II (4 $\mu \mathrm{M})$ (Yanagisawa et al., 1992; Parker et al., 1997) blocked the effects of substance $\mathrm{P}$ on the burst frequency ( $n=6$ of 7) (Fig. $4 A$ ) and $\mathrm{CV}(n=5$ of 7 ; data not shown). After washout of spantide II for at least $1 \mathrm{hr}$, a second application of substance $\mathrm{P}$ could result in a significant increase in burst frequency $(n=3 ; p<0.05)$ (Figs. $1 C, 4 A)$. Spantide II alone significantly reduced the frequency of NMDA-evoked ventral root bursts $(n=5$ of $7 ; p<0.05)$ (Fig. $4 A$ ) and increased the $\mathrm{CV}$ ( $n=4$ of $7 ; p<0.05$; data not shown), suggesting that endogenous tachykinins may influence locomotor activity. This was further supported by the increase in NMDA-evoked burst frequency and reduction of the CV (data not shown) in the presence of the endopeptidase inhibitor phosphoramidon $(2-10 \mu \mathrm{M} ; n=7$ of 7) (Fig. $4 B$ ), which blocks neuropeptide breakdown and thus would be expected to increase endogenous tachykinin levels. The effects of a low concentration $(2 \mu \mathrm{M})$ of phosphoramidon usually recovered after washing for $2 \mathrm{hr}(n=4)$, suggesting that endogenous tachykinin levels were not increased sufficiently to elicit the long-lasting network potentiation. With $10 \mu \mathrm{M}$ phosphoramidon, however, the effects lasted in excess of $5 \mathrm{hr}(n=3$; data not shown).

Substance P thus has two effects on the locomotor network: an increase in burst frequency and an improvement in the burst 
A

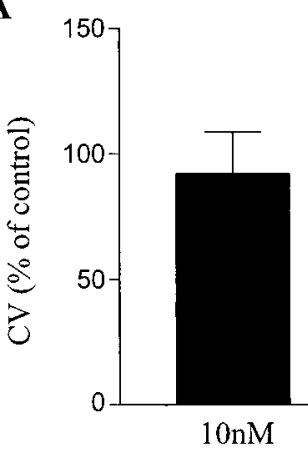

C

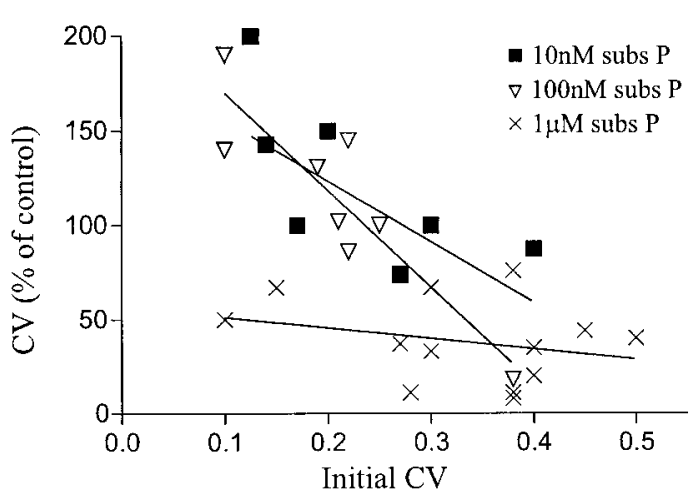

B

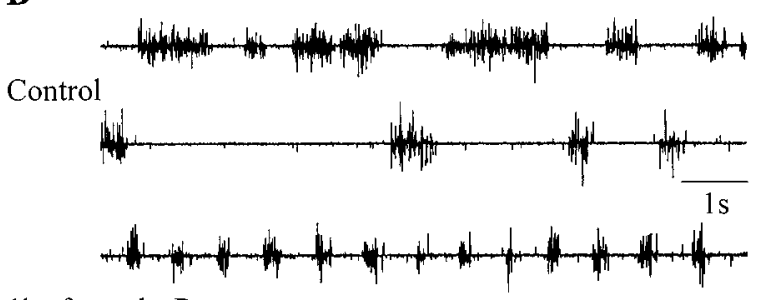

1h after subs $\mathrm{P}$

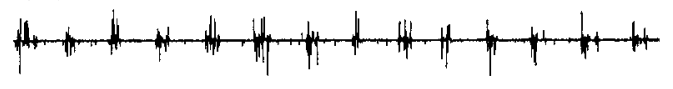

D

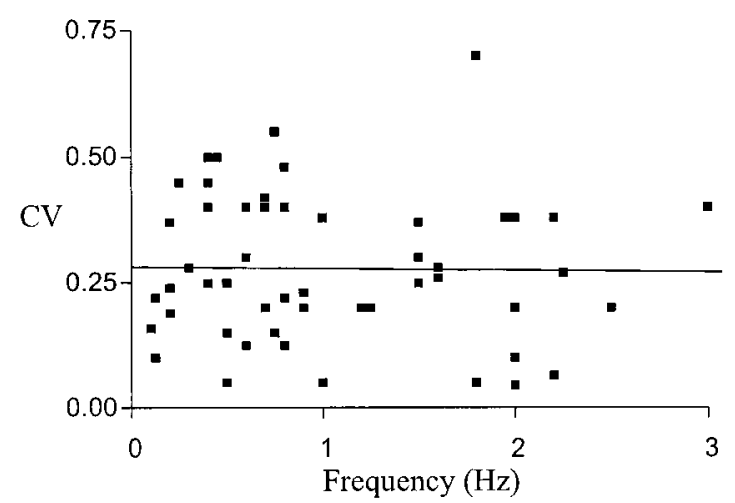

Figure 2. Substance $\mathrm{P}$ makes the locomotor activity more regular. $A$, This was shown quantitatively by a reduction of the coefficient of variation $(C V$; $\mathrm{SD}$ divided by mean cycle duration), the effects of substance $\mathrm{P}$ again being concentration-dependent $(10 \mathrm{nM}, n=8 ; 100 \mathrm{nM}, n=8 ; 1 \mu \mathrm{M}, n=63)$. $B$, Traces showing ventral root activity on both sides of the spinal cord in control, and $1 \mathrm{hr}$ after the application of $1 \mu \mathrm{M}$ substance $\mathrm{P}$ for 10 min. $C$, The reduction of the $C V$ with $10 \mathrm{~nm}$ and $100 \mathrm{~nm}$ substance $\mathrm{P}$ was greatest when the initial $\mathrm{CV}$ was high. With $1 \mu \mathrm{M}$ substance $\mathrm{P}$, however, the $\mathrm{CV}$ was reduced regardless of its initial value. $D$, The reduction of the $\mathrm{CV}$ was not caused by the increased frequency of locomotor bursts, as shown by the lack of a relationship between frequency and CV of NMDA-evoked locomotor bursts in different experiments $(n=48)$.

regularity. With $1 \mu \mathrm{M}$ substance $\mathrm{P}$, which is in the physiological range reported for neuropeptides (Duggan, 1995), the effects can last in excess of $24 \mathrm{hr}$. The mechanisms underlying this long-term modulation have been examined in detail, and thus the remainder of the results section concentrates on the effect of $1 \mu \mathrm{M}$ substance $\mathrm{P}$ on the locomotor network.

\section{Modulation of non-NMDA-induced locomotor activity}

Insight into the mechanisms underlying the network modulation was first obtained by examining activity elicited by the nonNMDA receptor agonist kainate $(5-10 \mu \mathrm{M} ; n=4)$ (Brodin et al., 1985). Substance $P$ significantly increased the frequency of kainate-evoked locomotor bursts (Fig. 5A,B) $(p<0.01)$ and reduced the $\mathrm{CV}$ (Fig. 5C) $(p<0.05)$, both effects lasting in excess of $7 \mathrm{hr}(n=4)$. However, if substance $\mathrm{P}$ was applied in the presence of the NMDA receptor antagonist AP-5 (100 $\mu \mathrm{M} ; n=$ 4), the modulation of the burst frequency was blocked (Fig. $5 B$, open symbols), suggesting that it was dependent on the intrinsic activation of NMDA receptors on network neurons. Application of AP-5 $3 \mathrm{hr}$ after substance P, however, did not reverse the effect on the burst frequency (Fig. $5 B$, filled symbols), suggesting that NMDA receptors are required only in the initial period after substance $\mathrm{P}$ application. In contrast to the effect on the burst frequency, application of substance P in the presence of $100 \mu \mathrm{M}$ AP-5 did not block the reduction of the CV $(n=4)$ (Fig. $5 C)$, further supporting the independence of the two substance P-induced network effects. Because the modulation of the CV was blocked by applying substance $\mathrm{P}$ in the absence of NMDA, and thus network activity (Fig. 3B), this result suggests that network activity, and not the presence of NMDA per se, is required for the development of the $\mathrm{CV}$ modulation.

\section{The effects of substance $P$ on cellular responses to NMDA}

Because the above results suggest an effect of substance $\mathrm{P}$ on NMDA receptors as a possible mechanism underlying the burst frequency modulation, the effects of substance $\mathrm{P}$ on cellular responses to NMDA were examined. This was done by recording intracellularly from network neurons and pressure-applying NMDA (1 mM; 10-100 msec) onto the surface of the spinal cord above the cell body from which the recording was made. TTX (1.5 $\mu \mathrm{M}$ ) was used to reduce indirect effects caused by the activation of nearby neurons. Bath application of $1 \mu \mathrm{M}$ substance P for $10 \mathrm{~min}$ significantly $(p<0.05)$ potentiated the amplitude of NMDA responses in motor neurons $(n=6$ of $6 ; 96 \pm 23 \%)$ (Fig. 6Ai,Aii), CC interneurons $(n=3$ of $3 ; 56 \pm 8 \%$ ) (Fig. 6Bi,Bii), and unidentified gray matter neurons ( $n=9$ of $10 ; 67 \pm 11 \%$; data not shown). Substance $\mathrm{P}$ had no measurable effect on the input resistance of any neuron (Fig. 6 $\mathrm{Ai}$, Bi, bottom traces). In addition to the effect on the amplitude, the duration of NMDA responses was usually increased in motor neurons ( $n=4$ of 6) (Fig. 6Aii) but was not affected in any CC interneuron $(n=3)$ (Fig. 6Bii). Responses to AMPA (1 mM) were not affected in any neuron when examined for up to $1 \mathrm{hr}$ after substance $\mathrm{P}$ application $(n=$ 4; data not shown). Potentiated NMDA responses and monosynaptic glutamatergic inputs always recovered gradually to control 
A

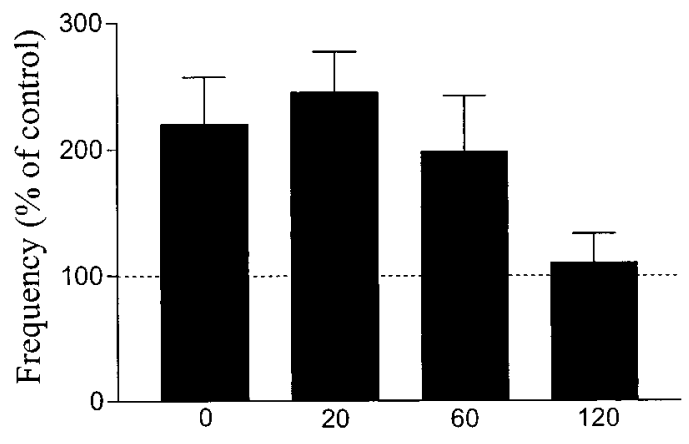

Time of NMDA application $(\mathrm{min})$
B

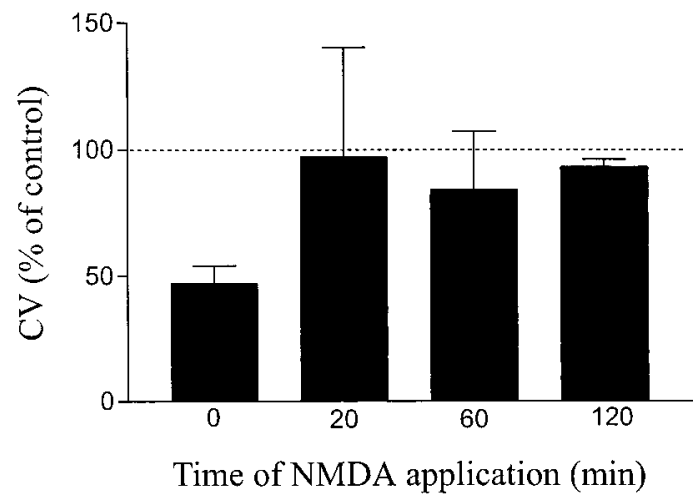

Figure 3. The effects of substance $\mathrm{P}$ on the burst frequency did not require the presence of substance $\mathrm{P}$ or network activity. This was shown by washing out NMDA after the control frequency $(A)$ and CV $(B)$ had been established. Substance $\mathrm{P}(1 \mu \mathrm{M})$ was applied 30 min after all locomotor activity had stopped. NMDA was then reapplied at different times after the washout of substance $\mathrm{P}$ had started. Numbers underneath the bars indicate the time (in minutes) when NMDA was reapplied after substance P washout. 0 means that substance $P$ was applied in the presence of NMDA. Data from three cords are shown at each time.

A

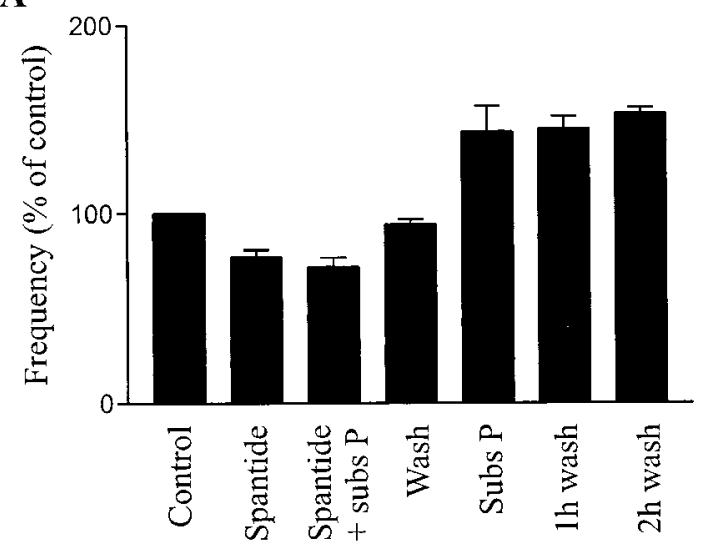

B

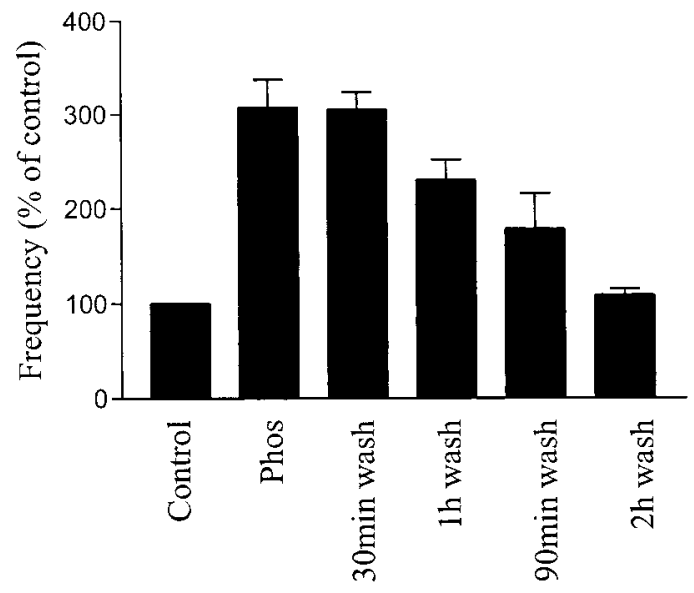

Figure 4. $A$, The tachykinin antagonist spantide $(4 \mu \mathrm{M})$ reduced the frequency of ventral root bursts and blocked the effects of $1 \mu \mathrm{M}$ substance P. After wash-off of spantide for at least $1 \mathrm{hr}$, application of substance $\mathrm{P}$ resulted in an increase in the burst frequency. $B$, Bath application of the peptidase inhibitor phosphoramidon $(2 \mu \mathrm{M})$ in the absence of exogenously applied substance $\mathrm{P}$ also increased the frequency of ventral root bursts, suggesting a potentiating effect of endogenous tachykinin levels. Data from three experiments are shown in $A$ and from four experiments in $B$.

after washing (mean recovery time of NMDA responses, $92 \pm 32$ min; $n=18$ ) (Fig. 6Ai,Bi) (Parker and Grillner, 1998). Thus, although the potentiation of NMDA responses, and consequently synaptic inputs, may have a role in the early stage of the network modulation, the long-term effect presumably does not depend on the tonic modulation of NMDA responses. This is in agreement with the results obtained by examining the effects of AP-5 application on potentiated kainate-evoked activity 3-4 hr after substance $\mathrm{P}$ (Fig. 5B).

\section{Role of the glycine site and magnesium block in the modulation of cellular NMDA responses}

The mechanisms by which substance $\mathrm{P}$ potentiated NMDA responses were also examined. NMDA responses can be modulated by an effect at the glycine binding site of the receptor (Johnson and Asher, 1986; Rusin et al., 1992) or by an effect on the magnesium block of the channel (Mayer et al., 1984; Chen and Huang, 1992). NMDA receptors in lamprey also have a glycine binding site and exhibit magnesium block (Brodin and Grillner, 1986; Grillner et al., 1991). The role of the glycine binding site in the modulation of NMDA responses was examined by adding 1-5 $\mu \mathrm{M}$ glycine to the Ringer's solution. These concentrations have been used to saturate the glycine site of rat NMDA receptors, thus occluding the effect of substance $\mathrm{P}$ at the glycine binding site (Rusin et al., 1992). In the lamprey, glycine application resulted in the potentiation of NMDA responses ( $n=3$ unidentified gray matter neurons) (Fig. 6C). However, when substance $\mathrm{P}$ was applied in the presence of glycine, it was still able to significantly potentiate NMDA responses to a similar degree $(n=3 ; p<0.05)$ (Fig. $6 C$ ), suggesting that it acts independently of the glycine site.

The modulation of the magnesium block of the NMDA channel by substance $\mathrm{P}$ was investigated by bath-applying nominally magnesium-free Ringer's solution after the recovery of the effects of substance $\mathrm{P}$ on NMDA responses $(n=3$ unidentified gray matter neurons). As with glycine, magnesium-free Ringer's solution potentiated NMDA responses. However, subsequent application of substance $\mathrm{P}$ again significantly potentiated NMDA responses $(n=3 ; p<0.05)$ (Fig. $6 D)$, suggesting that substance $\mathrm{P}$ does not affect the magnesium block of the channel. 
A

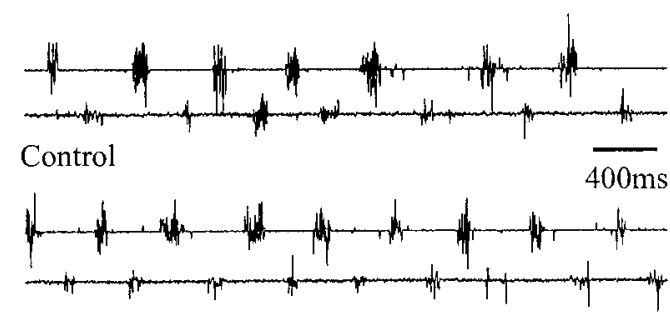

Substance $P$

C

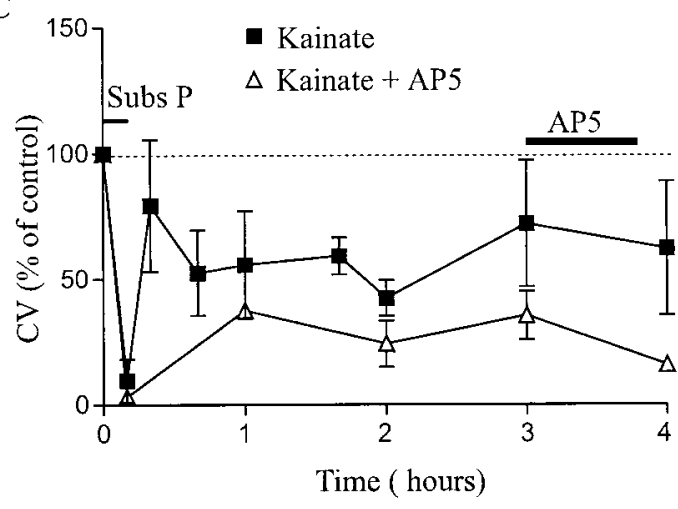

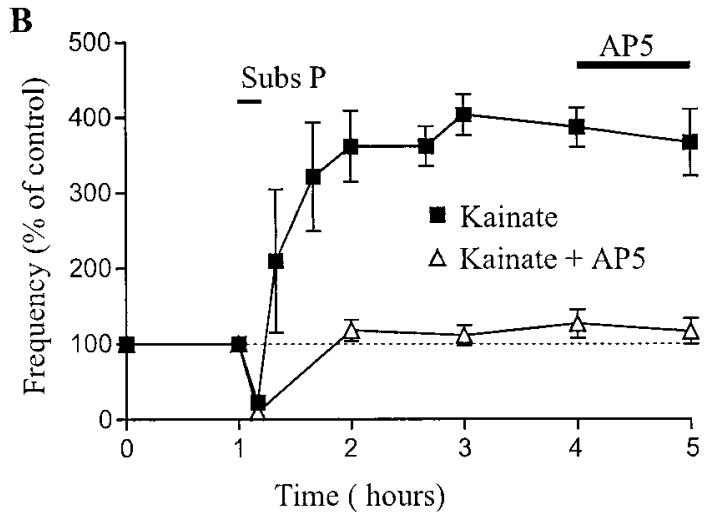

Figure 5. Substance P modulates non-NMDA-mediated locomotor activity. $A$, Bath application of $1 \mu \mathrm{M}$ substance $\mathrm{P}$ increased the frequency and reduced the $\mathrm{CV}$ of locomotor bursts elicited by $10 \mu \mathrm{M}$ kainate. Graphs show the effect of $10 \mathrm{~min}$ application of $1 \mu \mathrm{M}$ substance $\mathrm{P}$ on the frequency $(B)$ and $\mathrm{CV}(C)$ of kainate-evoked ventral root bursts in control and in the presence of $100 \mu \mathrm{M}$ AP-5. Bar above the graph indicates the onset and duration of substance P and AP-5 (100 $\mu \mathrm{M})$ application. Data from four AP-5-incubated and four non-AP-5-incubated cords are shown in $B$ and $C$.

\section{Tachykinin effects on NMDA responses are mediated via protein kinase $\mathbf{C}$}

The second messenger pathway through which substance $\mathrm{P}$ acts to potentiate NMDA responses was also examined. Because substance $\mathrm{P}$ activates protein kinase $\mathrm{C}$ (PKC) in mechanosensory neurons in the lamprey (Parker et al., 1997) and PKC can potentiate NMDA responses in other systems (Ben Ari et al., 1992), including the spinal cord (Gerber et al., 1992), the role of PKC was examined. Bath application of the PKC-activating phorbol ester phorbol 12,13-dibutyrate $(10 \mu \mathrm{M})$ significantly potentiated responses to NMDA in unidentified gray matter neurons $(n=4$; $p<0.05$ ) (Fig. 7Ai,Aii), an effect that was reversed by the PKC inhibitor chelerythrine (10 $\mu \mathrm{M} ; n=3)$ (Fig. 9Ai,Aii). The inactive analog 4- $\alpha$ phorbol 12,13-dibutyrate did not significantly affect NMDA responses $(n=4 ; p>0.1$; data not shown). These results suggest that PKC can potentiate NMDA responses in lamprey gray matter neurons. The role of PKC in the substance P-mediated modulation of NMDA responses was examined by bath-applying chelerythrine $(10 \mu \mathrm{M})$ for $1 \mathrm{hr}$ after the initial effects of substance P had recovered to control $(n=4)$. This treatment has been shown to block the PKC-mediated modulation of mechanosensory afferents in the lamprey (Parker et al., 1997). Chelerythrine consistently blocked the effects of substance $\mathrm{P}$ on NMDA responses (Fig. 7Bi,Bii), suggesting that substance $\mathrm{P}$ acts through PKC.

\section{Second messenger pathways underlying the network modulation}

The results presented above show that substance $\mathrm{P}$ potentiates NMDA responses by acting through PKC. Confirmation of the role of this potentiation in the network modulation was examined in two ways. First, because the modulation of NMDA responses is dependent on PKC, the modulation of the burst frequency should also be blocked by the PKC antagonist chelerythrine if it is dependent on the potentiation of NMDA responses. This was examined by preincubating spinal cords with chelerythrine (10 $\mu \mathrm{M})$ for $1 \mathrm{hr}$ before substance P application. Chelerythrine on its own did not significantly affect the CV or frequency of NMDAelicited ventral root bursts $(p>0.1)$ (Fig. 8Ai,Aii), but it did block the modulatory effects of substance $\mathrm{P}$ on the burst frequency ( $n=4$ of 6) (Fig. 8Ai), as would be expected if the potentiation of NMDA responses was required for the burst frequency modulation to occur. Chelerythrine also blocked the modulation of the CV (Fig. 8Aii). The burst frequency and CV modulation developed as usual in cords taken from the same animals but not incubated in chelerythrine $(n=6)$ (Fig. 8Ai, Aii).

Preincubation with the cAMP- and cGMP-dependent protein kinase inhibitor H8 $(10 \mu \mathrm{M})$ for $1 \mathrm{hr}$ also did not significantly affect the frequency or $\mathrm{CV}$ of control locomotor activity $(p>$ 0.1 ), or, in contrast to the effects of chelerythrine, the substance P-mediated potentiation of the burst frequency ( $n=3$ of 5) (Fig. $8 \mathrm{Bi}$ ). However, $\mathrm{H} 8$ did block the substance P-mediated reduction of the CV ( $n=4$ of 5) (Fig. 8Bii). Thus, the modulation of the $\mathrm{CV}$ is blocked by inhibitors of both PKC and cAMP- and cGMPdependent protein kinases, again suggesting that separate effects underlie the modulation of the burst frequency and CV.

Because NMDA receptors are permeable to calcium (Mayer and Westbrook, 1987), including those in lamprey (Wallén and Grillner, 1987), potentiation of their responses would be expected to increase calcium levels in network neurons, an effect that has been suggested to underlie the induction of long-term potentiation in the hippocampus (Bliss and Collingridge, 1993). The role of calcium in the modulation of the lamprey locomotor network was examined by incubating spinal cords in the slow intracellular calcium chelator EGTA-AM $(20 \mu \mathrm{M})$. EGTA-AM is a membrane permeable analog of EGTA. Once inside the cell, ester groups are removed, enabling it to buffer calcium but prevent it from leaving the cell. In these experiments, two pieces of cord were taken from the same animal. One piece was exposed to substance $\mathrm{P}$ as normal, whereas the other piece was incubated in EGTA-AM for $2 \mathrm{hr}$. EGTA-AM did not significantly affect con- 

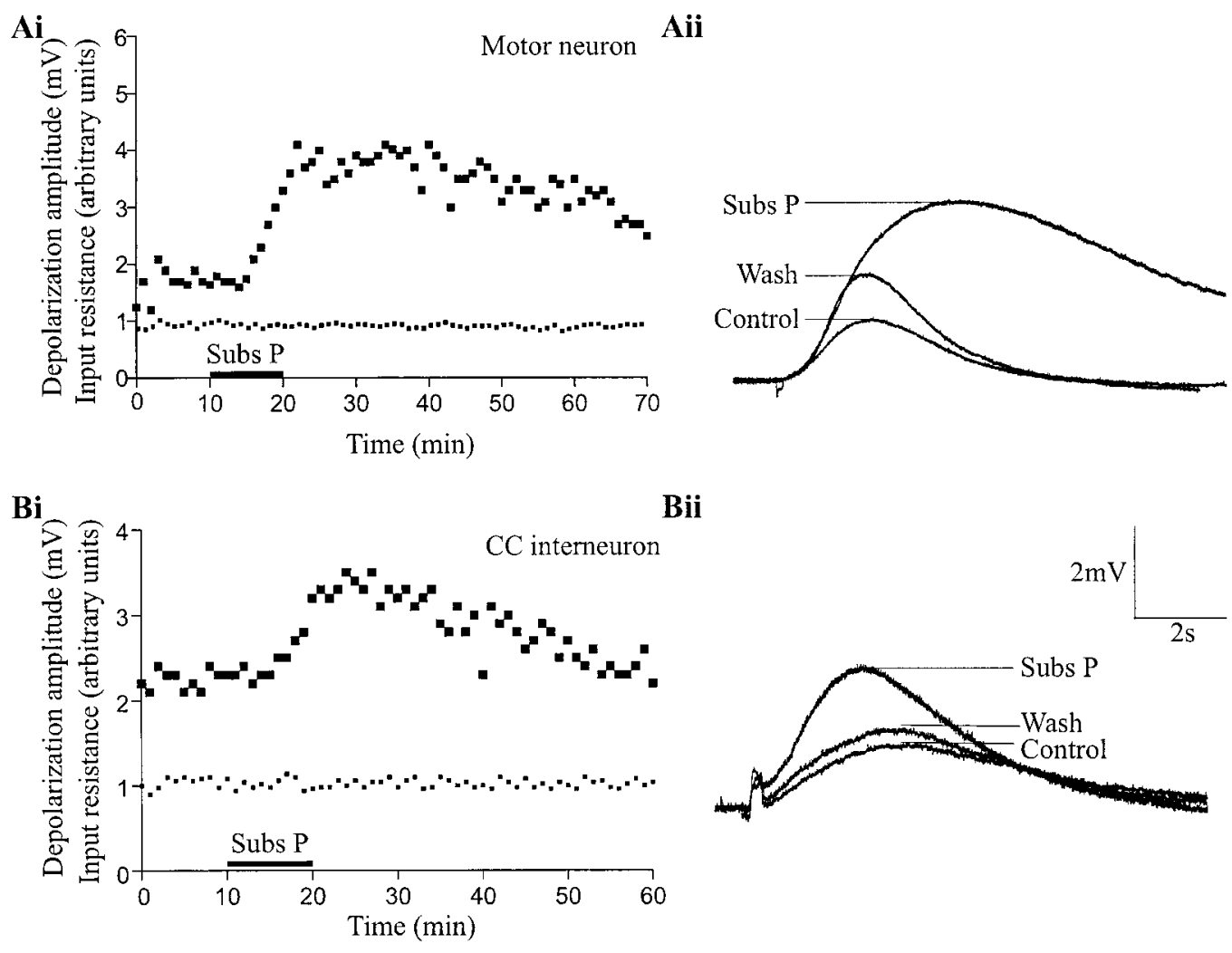

Bii

C
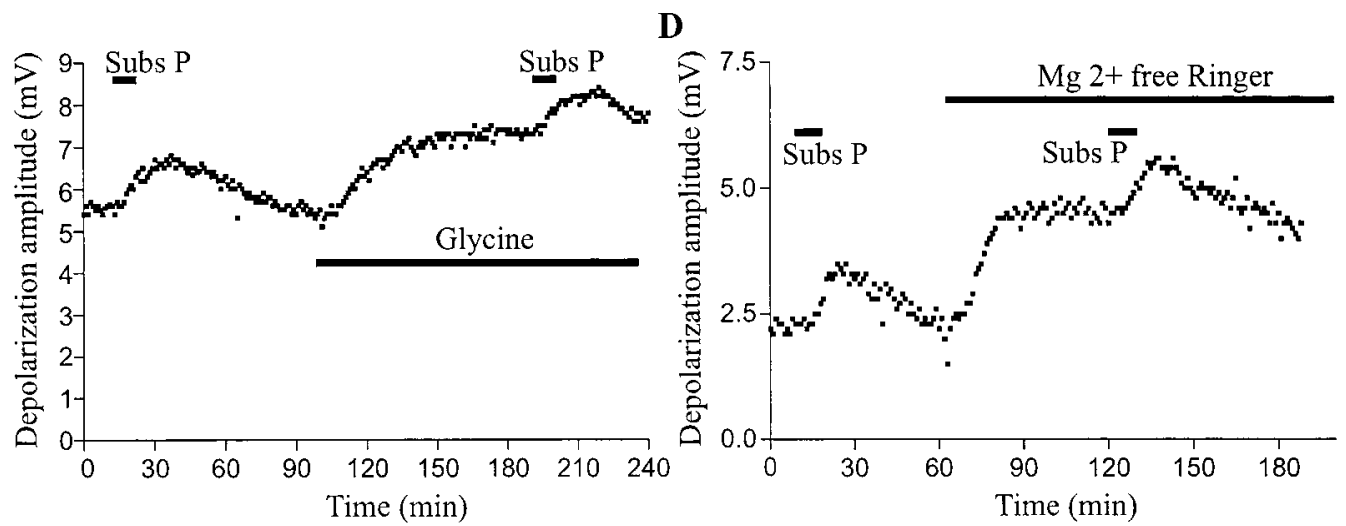

Figure 6. Substance $\mathrm{P}$ potentiates cellular responses to NMDA. The effects of $1 \mu \mathrm{M}$ substance $\mathrm{P}$ on responses to pressure-applied NMDA (1 mM) in an identified motor neuron $(A i, A i i)$ and a CC interneuron $(B i, B i i)$ are shown. NMDA was applied in the presence of $1.5 \mu \mathrm{M}$ TTX. The bottom trace on each graph shows the lack of effect of substance $\mathrm{P}$ on the input resistance of the neuron during the experiment. The effects of substance $\mathrm{P}$ in unidentified gray matter neurons persisted in the presence of bath-applied glycine $(5 \mu \mathrm{M})(C)$ and in nominally magnesium-free Ringer's solution $(D)$. Graphs show representative data from a single experiment in each case.

trol locomotor activity $(n=7)$ (Fig. $9 A i)$, the only effect being a slight increase in burst frequency $(p>0.05$; two-tailed paired $t$ test). In contrast, incubation with the fast intracellular calcium chelator BAPTA-AM (20 $\mu \mathrm{M}$ for $2 \mathrm{hr})$ severely disrupted locomotor activity $(n=4)$ (Fig. 9Aii). This suggests that as in most other systems (Adler et al., 1991; Hochner et al., 1991; Ouanounou et al., 1996), EGTA is not able to buffer the calcium transients required for fast transmitter release. Although the effect of substance $\mathrm{P}$ on the burst frequency in EGTA-AM-treated cords was significant $(n=6 ; p<0.05)$, the effect was markedly reduced compared with that in untreated cords $(n=6)$ (Fig. 9B). In addition, the potentiation that did develop in the EGTA-AMtreated cord had largely recovered after washing for $4 \mathrm{hr}$. The reduction of the $\mathrm{CV}$ was also blocked in cords incubated with
EGTA-AM (Fig. 9C). These results suggest that an increase in intracellular calcium is necessary for the modulation of the burst frequency and $\mathrm{CV}$, and although this calcium could potentially come from several sources, it provides support for the link between the substance P-mediated modulation of NMDA receptors and the network modulation.

\section{Effect of protein synthesis inhibitors on the long-term modulation}

The results presented above show that substance $\mathrm{P}$ modulates the burst frequency and $\mathrm{CV}$. The burst frequency modulation appears to be dependent on a PKC-mediated potentiation of NMDA responses and increased intracellular calcium levels. However, because the potentiation of cellular responses to 
$\mathrm{Ai}$

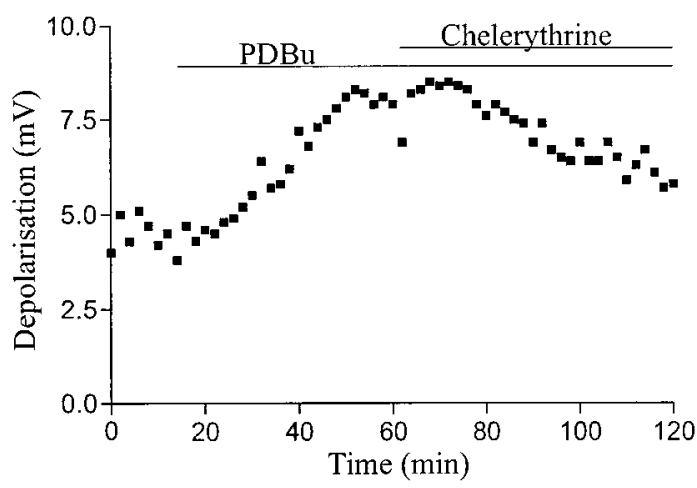

Bi

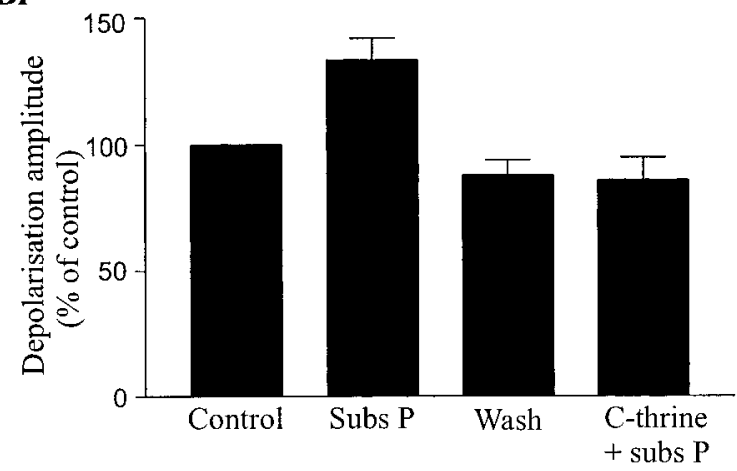

Aii

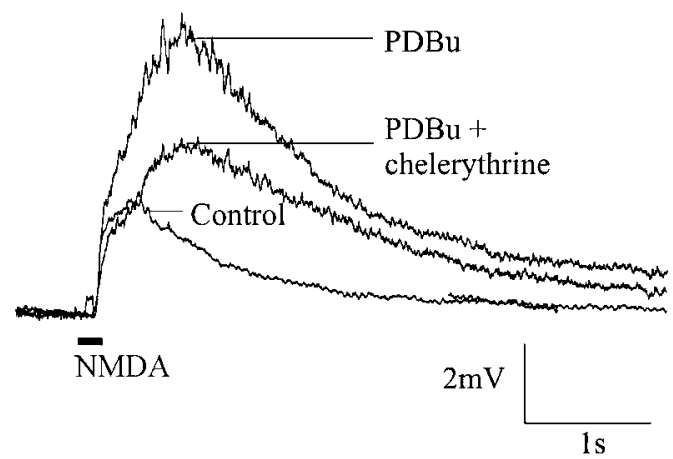

Bii

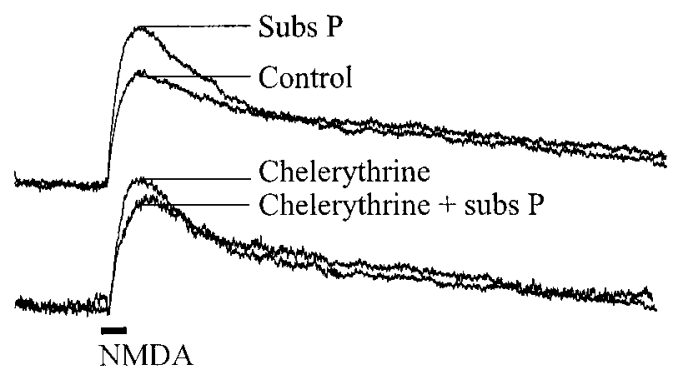

Figure 7. The effects of substance $\mathrm{P}$ on cellular responses to NMDA are mediated by protein kinase C. Ai, Aii, Bath application of phorbol 12,13-dibutyrate $(10 \mu \mathrm{M})$ potentiated the responses to pressure-applied NMDA in an unidentified gray matter neuron. This effect was reversed by the protein kinase $\mathrm{C}$ antagonist chelerythrine $(10 \mu \mathrm{M}) . B i$, Bii, Chelerythrine $(10 \mu \mathrm{M})$ also blocked the potentiation of NMDA responses elicited by bath application of $1 \mu \mathrm{M}$ substance P. $B i$, Data from four unidentified gray matter neurons showing the effects of substance $\mathrm{P}$ in control and in the presence of chelerythrine.

NMDA does not last in excess of $2 \mathrm{hr}$, the modulation of NMDA responses cannot directly account for the long-term modulation. Two mechanisms that may underlie long-term changes in the nervous system, tonic activation of protein kinases (Greenberg et al., 1987; Thomas et al., 1994) and synthesis of new protein (Montarolo et al., 1986; Rose, 1991; Fazeli et al., 1993), were thus examined.

The role of tonic protein kinase activation was examined by bath-applying PKC and cAMP- and cGMP-dependent protein kinase inhibitors $4 \mathrm{hr}$ after the application of substance $\mathrm{P}$, thus at a time when the putative NMDA-dependent induction mechanism had decayed and the maintenance mechanism should be established. In these experiments, H8 $(n=4 ; 10 \mu \mathrm{M})$ and chelerythrine $(n=5 ; 10 \mu \mathrm{M})$ failed to affect the modulated burst frequency (Fig. $8 \mathrm{Ci})(p>0.1)$ or $\mathrm{CV}$ (Fig. 8Cii) (chelerythrine $p>0.1$; H8 $p>0.05)$. These results suggest that the tonic activation of protein kinases is not required for the maintenance of the burst frequency or CV modulation.

Protein synthesis is required for long-lasting effects in several systems (Montarolo et al., 1986; Dale et al., 1987; Rose, 1991; Fazeli et al., 1993). The role of protein synthesis in the long-term modulation of the lamprey network was examined by incubating spinal cords with the translational protein synthesis inhibitors anisomycin, puromycin, or cyclohexamide. In these experiments, two pieces of cord were again taken from the same animal, one cord being used as a control, whereas the other was incubated in translational inhibitors $(10 \mu \mathrm{M})$ for $1-4 \mathrm{hr}$. The effects of substance $\mathrm{P}$ in anisomycin-treated cords initially resembled that in the untreated cord. However, in every case the burst frequency recovered to control after washing for $2-3 \mathrm{hr}$ ( $n=7$ of 7) (Fig. $10 \mathrm{Ai}$ ). In untreated cords taken from the same animals, substance $\mathrm{P}$ resulted in the typical prolonged increase in burst frequency $(n=7)$. Puromycin $(n=3$ of 3$)$ and cyclohexamide $(n=2$ of 2$)$ mimicked the effects of anisomycin (data not shown); however, cyclohexamide $(n=4)$ could severely disrupt control locomotor activity, an effect not seen with anisomycin or puromycin (data not shown).

The effects of protein synthesis inhibitors on the $\mathrm{CV}$ again differed from that on the burst frequency. The modulation of the $\mathrm{CV}$ did not recover in anisomycin-treated cords ( $n=4$ of 7) (Fig. $10 \mathrm{Aii}$ ), at least not at the 2-3 hr stage. Similar effects were seen with puromycin ( $n=3$ of 3 ). These results suggest that the long-term modulation of the $\mathrm{CV}$ may not depend on new protein synthesis.

Protein synthesis inhibitors typically have a time window of effectiveness (Bergold et al., 1990; Freeman et al., 1995). The time window during which application of protein synthesis inhibitors was able to block the prolonged substance P-mediated modulation of the burst frequency was examined by applying anisomycin at different times before and after substance $\mathrm{P}$ application. The long-term modulation was blocked when the cord was preincubated with anisomycin for $1-4 \mathrm{hr}$ before substance $\mathrm{P}(n=7)$ (Fig. 10). Application of anisomycin $30 \mathrm{~min}$ after substance $\mathrm{P}$ also blocked the long-term modulation of the burst frequency $(n=4$; data not shown). Application of anisomycin $1 \mathrm{hr}$ after substance $\mathrm{P}$ had more variable effects, with the long-term modulation being 
$\mathbf{A i}$
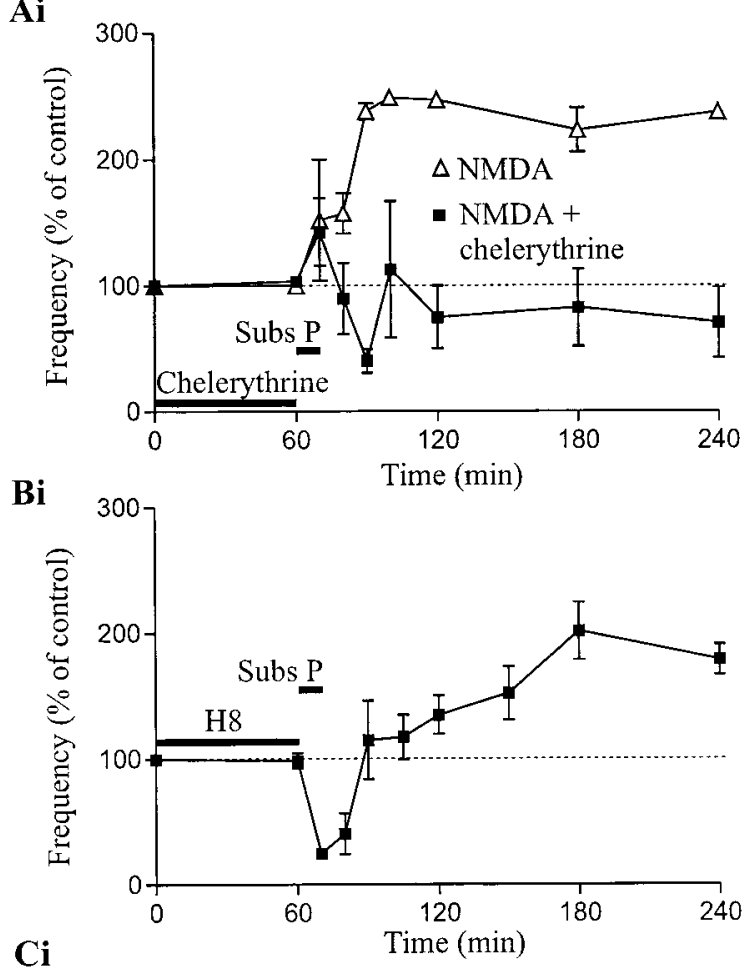

$\mathbf{C i}$

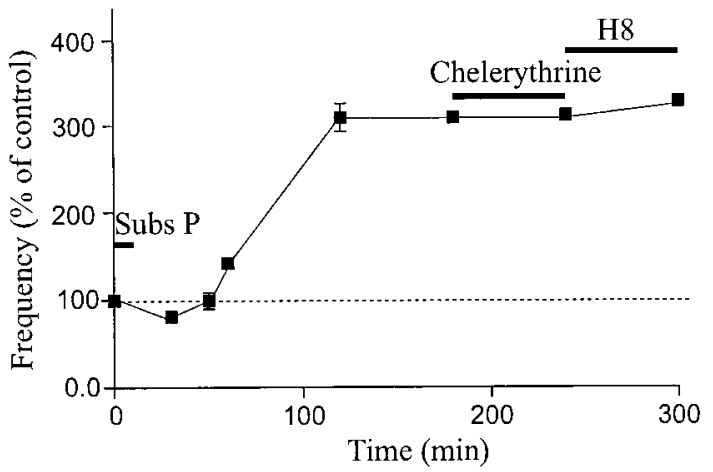

Aii
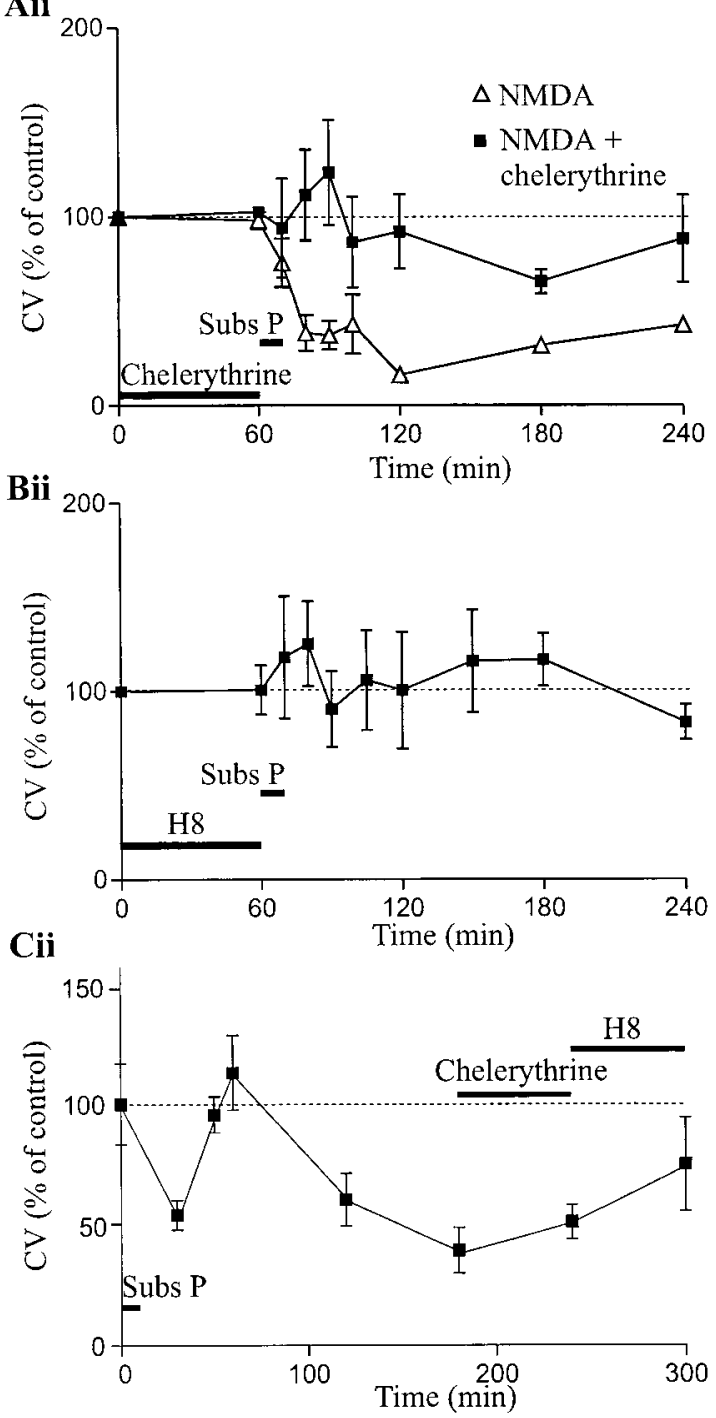

Figure 8. The role of protein kinases in the network potentiation. Bath application of the protein kinase $\mathrm{C}$ antagonist chelerythrine (10 $\mu \mathrm{M})$ blocked the increase in the frequency of NMDA-evoked locomotor bursts $(A i)$ and the reduction of the CV (Aii). H8, an inhibitor of cAMP- and cGMP-dependent protein kinases, did not block the increased burst frequency $(B i)$, but it did block the reduction of the CV $(B i i)$. Chelerythrine and $\mathrm{H} 8$ did not affect the frequency $(\mathrm{Ci})$ or $\mathrm{CV}(\mathrm{Cii})$ of locomotor bursts when applied 3-4 hr after substance P. $A i, A i i, n=6$; $B i, B i i, n=5 ; C i, C i i$, chelerythrine, $n=5 ; \mathrm{H} 8, n=4$.

blocked in three of five cords (data not shown). Application of anisomycin 2 or $4 \mathrm{hr}$ after substance $\mathrm{P}$ failed to affect the longterm network modulation in any cord $(n=7)$ (Fig. 10). These results thus suggest that protein synthesis inhibitors are effective up to $\sim 1 \mathrm{hr}$ after substance $\mathrm{P}$ application.

\section{Blockade of D2 receptors may induce a tachykinin-mediated potentiation}

Colocalized dopamine and 5-HT both modulate NMDA-elicited fictive locomotion (Harris-Warrick and Cohen, 1985; McPherson and Kemnitz, 1994). When the effects of dopamine and 5-HT receptor antagonists on locomotor activity were examined, the dopamine D2 receptor antagonist eticlopride $(20 \mu \mathrm{M})$ (Köhler et al., 1986) was found to potentiate the burst frequency and reduce the CV. Application of eticlopride for periods of $<15 \mathrm{~min}$ resulted in a transient increase in burst frequency that recovered to control after washing for $1 \mathrm{hr}(n=15$; data not shown). However, application of eticlopride for $15-30$ min resulted in a significant increase in burst frequency $(n=25 ; p<0.05)$ (Fig. 11A,B) and reduction of the $\mathrm{CV}(n=25 ; p<0.05$; data not shown) that persisted after wash-off of $10 \mathrm{hr}$ (Fig. 11B). This effect occurred over the range of NMDA concentrations used, although the effects were greater at lower initial frequencies (data not shown). In contrast to the effect of substance $\mathrm{P}$, the effect of eticlopride on the burst frequency required the presence of NMDA or activation of the locomotor network or both, because it failed to develop when eticlopride was applied after washout of NMDA (data not shown).

Because the time course of the prolonged eticlopride-mediated modulation resembled that of the effects of $1 \mu \mathrm{M}$ substance P (Fig. $1 C)$, a role for tachykinins in the eticlopride-mediated modulation was sought by applying eticlopride in the presence of the tachykinin antagonist spantide II. In the presence of spantide II ( $4 \mu \mathrm{M})$, eticlopride resulted in only a transient increase in burst frequency $(n=7)$ (Fig. $11 C)$, similar to that seen after short $(<15 \mathrm{~min})$ 
$\mathbf{A i}$

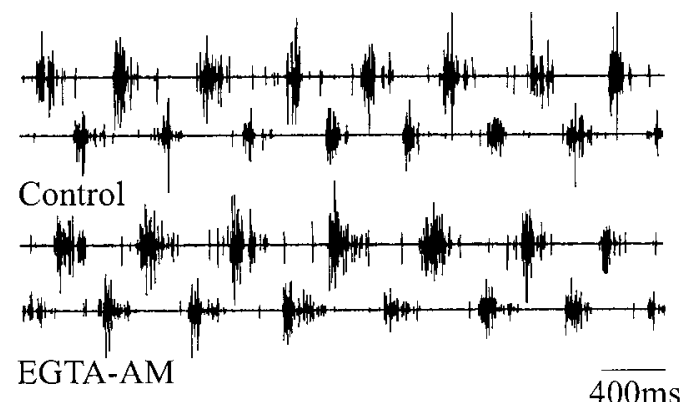

B

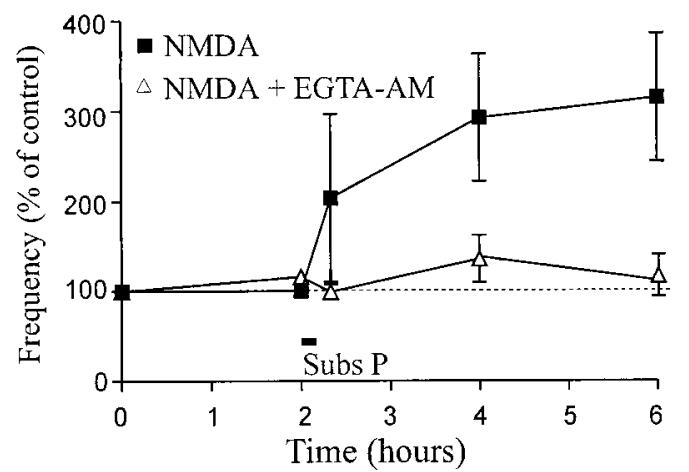

Aii

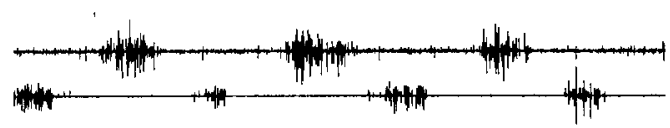

Control

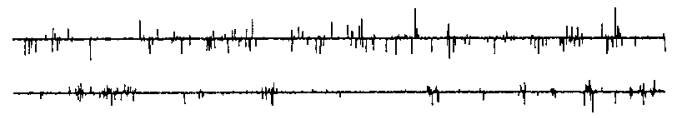

BAPTA-AM
$\mathrm{C}$

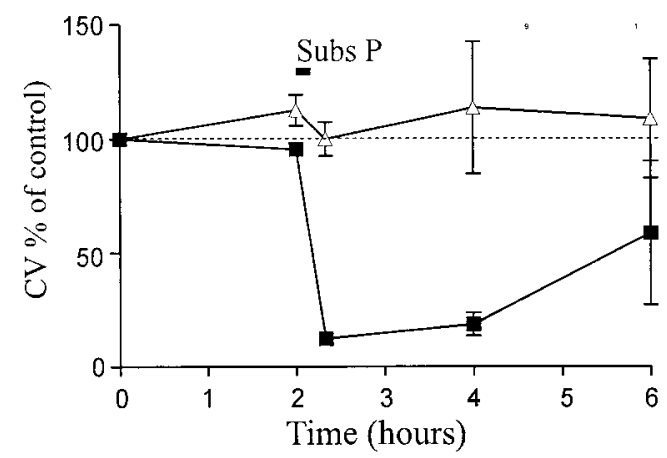

Figure 9. Bath application of the intracellular calcium chelator EGTA-AM (20 $\mu \mathrm{M}$ for $2 \mathrm{hr})$ resulted in a smaller, reversible effect of substance P on the burst frequency and blocked the effect on the CV. Ai, Aii, Traces showing the effects of EGTA-AM and BAPTA-AM (20 $\mu \mathrm{M}$ for $2 \mathrm{hr})$ on locomotor activity. Effects of substance P on NMDA-evoked burst frequency $(B)$ and CV $(C)$ in cords incubated in EGTA-AM. Data from six EGTA-AM-treated and six non-EGTA-treated cords are shown.

applications of eticlopride. After wash-off of spantide II, eticlopride application (15-30 $\mathrm{min}$ ) again resulted in a prolonged significant increase in burst frequency $(n=7 ; p<0.05)$ (Fig. $11 C$ ). This effect of spantide II suggests that tachykinins are involved in the eticlopride-mediated modulation, possibly because of the endogenous release of tachykinins from the ventromedial plexus.

\section{DISCUSSION}

These results show that substance $\mathrm{P}$ and other tachykinins modulate the lamprey locomotor network by increasing the frequency and improving the regularity of the burst activity. Similar effects on burst frequency and $\mathrm{CV}$ have been shown for substance $\mathrm{P}$ on lumbar locomotor networks in the neonatal rat (Barthe and Clarac, 1997), although the underlying mechanisms have not been examined. With $1 \mu \mathrm{M}$ substance P, which is in the physiological concentration range reported for neuropeptides (Duggan, 1995), the modulation lasts in excess of $24 \mathrm{hr}$. Tachykinin release can thus reset the sensitivity of the locomotor network to glutamatergic locomotor drive signals.

We do not know yet on which tachykinin receptor substance $\mathrm{P}$ acts, but it does not appear to resemble the mammalian NK1 receptor, because a specific NK1 receptor antagonist did not block the effects of substance $\mathrm{P}$ and the effects were mimicked by neurokinin A. The effects were tachykinin-mediated, however, because in addition to neurokinin $\mathrm{A}$, the molluscan tachykinin eledoisin and the amphibian tachykinin physalaemin all mimicked the effects of substance P, whereas the effects were blocked by the tachykinin antagonist spantide II. Immunohistochemical and HPLC analysis have suggested the presence of three different tachykinins in the lamprey. However, these are not identical to substance P, neurokinin A, or neurokinin B (Van Dongen et al., 1986). The functionally important C-terminal sequence, however, appears to have been conserved (Waugh et al., 1995), presumably allowing substance $\mathrm{P}$ to act as an agonist at the endogenous receptor(s).

\section{Evidence for endogenous activation of tachykinin receptors}

Exogenously administered tachykinins cause prolonged effects on the locomotor network. Endogenous tachykinin release also appears to cause corresponding effects. The tachykinin antagonist spantide II significantly reduced the frequency of NMDA-elicited ventral root bursts, whereas the endopeptidase inhibitor phosphoramidon potentiated the burst frequency and reduced the $\mathrm{CV}$, an effect that lasted for at least $5 \mathrm{hr}$ with higher concentrations. These results suggest that a low level of endogenous tachykinins is released during network activity. In addition, dopaminergic D2 receptors appear to influence the endogenous release of tachykinins, because administration of the D2 receptor antagonist eticlopride resulted in a spantide II-sensitive long-lasting increase in burst frequency and reduction of the coefficient of variation. The prolonged time course and sensitivity to tachykinin antagonists suggests that this effect was also mediated by tachykinins. Thus, dopamine, which is found in the ventromedial plexus (Van Dongen et al., 1986; Schotland et al., 1995), may regulate endogenous tachykinin release. This result provides indirect evidence that endogenous tachykinins affect the locomotor network. The effects of $\mathrm{D} 2$ receptors in controlling endogenous tachykinin release needs to be examined further. In addition, the role of endog- 
Ai

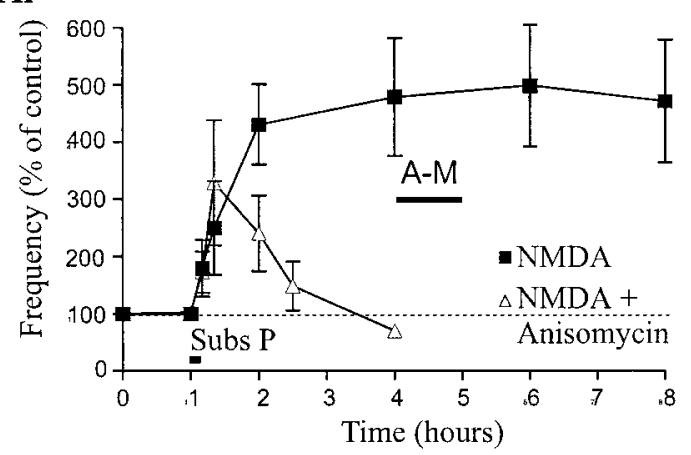

Bi

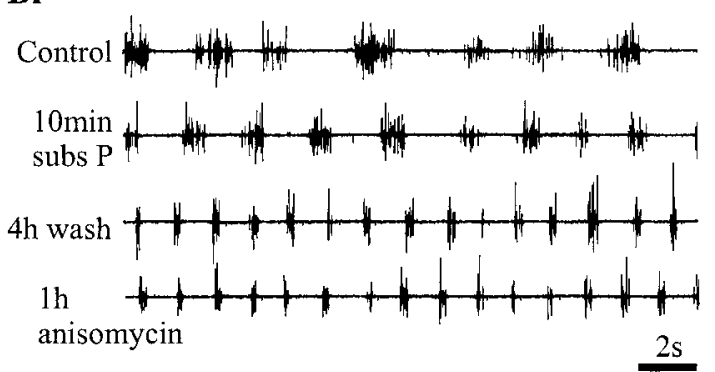

Aii

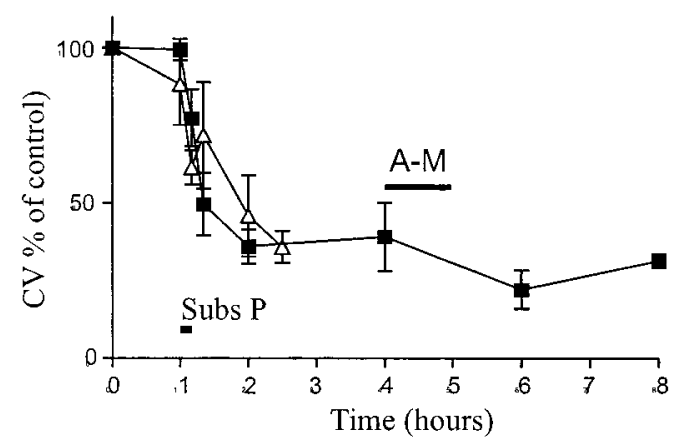

Bii

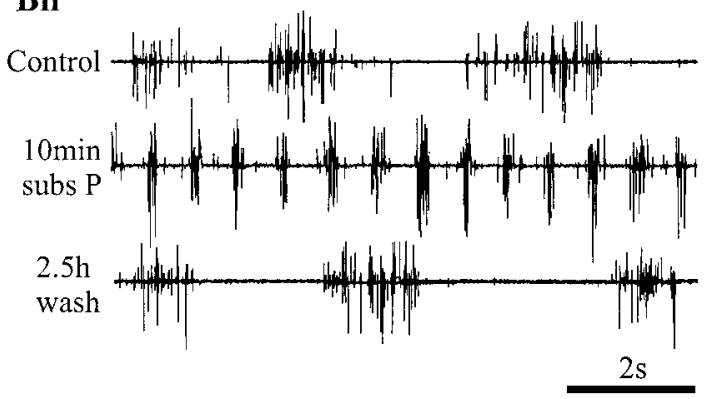

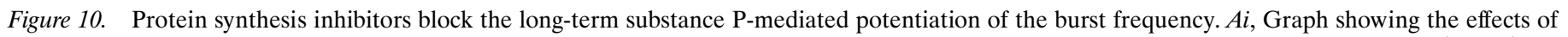

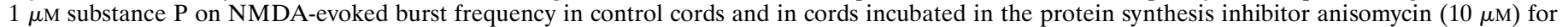

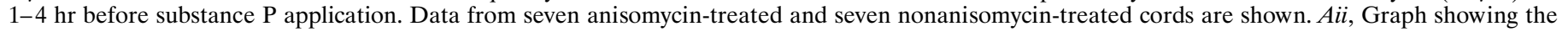

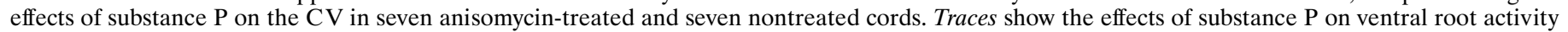
in a control $(B i)$ and an anisomycin-treated cord $(B i i)$.

enously released tachykinins in modulating locomotor activity under more natural conditions-for example, after brain stem or tail fin stimulation (McClellan and Grillner, 1984; Brodin and Grillner, 1985)—needs to be examined.

\section{The network effects of substance $\mathbf{P}$}

Tachykinins increased the frequency and reduced the $\mathrm{CV}$ of ventral root bursts. Several results suggest that these two effects have independent underlying mechanisms. First, there is no correlation between the $\mathrm{CV}$ and burst frequency, suggesting that the $\mathrm{CV}$ modulation was not simply a consequence of the increased burst frequency. Second, although the burst frequency modulation was NMDA-dependent, but did not require NMDA or network activity during substance $\mathrm{P}$ application for its induction, the modulation of the CV was NMDA-independent but required that substance $\mathrm{P}$ be applied in the presence of network activity. Third, the CV modulation was blocked by H8, an inhibitor of cAMP- and cGMP-dependent protein kinases, whereas the burst frequency modulation was unaffected. Finally, the long-lasting effect on the burst frequency was consistently blocked by protein synthesis inhibitors, whereas the effects of protein synthesis inhibitors on the $\mathrm{CV}$ modulation were more variable.

\section{Mechanisms contributing to the tachykinin-mediated modulation of burst frequency}

Of the two effects on the locomotor network, the mechanisms underlying the modulation of the burst frequency are known in most detail. There appear to be at least two phases contributing to this effect: one phase that lasts for up to $\sim 2 \mathrm{hr}$ and may contribute to the short-term effects of nM concentrations of substance $\mathrm{P}$ or the induction of the long-term effects or both, and a second long-lasting phase that begins $\sim 2-3 \mathrm{hr}$ after substance $\mathrm{P}$ application and is blocked by protein synthesis inhibitors.

Several lines of evidence suggest that the network modulation is dependent on the potentiation of glutamatergic synaptic transmission because of a specific effect on the NMDA component of the synaptic potential. First, substance P potentiated NMDAevoked network activity and cellular responses to NMDA, providing a correlational link between these effects; second, the network effects were blocked by intracellular calcium chelation, which because NMDA receptors can provide one source of this calcium (Mayer and Westbrook, 1987; Wallén and Grillner, 1987) provides support for the role of NMDA receptors in the network modulation; third, the potentiation of cellular responses to NMDA was PKC-dependent, and inhibitors of PKC also blocked the network modulation; fourth, although the modulation of the burst frequency did not require NMDA or network activity during substance $\mathrm{P}$ application, the effects were blocked if NMDA was not reintroduced to the bath within $\sim 1$ hr after substance $\mathrm{P}$, approximately matching the time course of the potentiation of NMDA responses; and finally, the effects of substance $\mathrm{P}$ on kainate-evoked locomotor activity were blocked when substance $\mathrm{P}$ was applied in the presence of the NMDA receptor antagonist AP-5. Taken together, these results strongly suggest that the potentiation of NMDA responses is central to the burst frequency modulation.

The modulation of NMDA responses is associated with an increase in the amplitude of monosynaptic glutamatergic EPSPs, shown by making paired recordings from presynaptic reticulospinal axons or excitatory interneurons and postsynaptic motor neurons or unidentified network neurons (Parker and Grillner, 1998; 


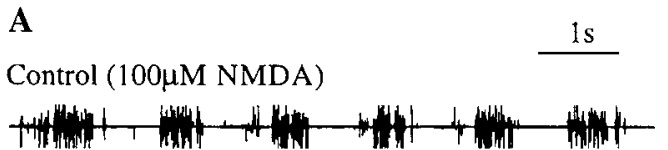

$15 \min 20 \mu \mathrm{M}$ eticlopride

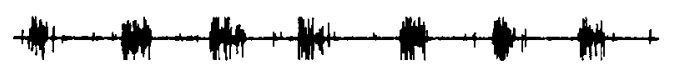

10h wash

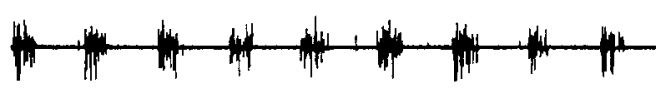

C

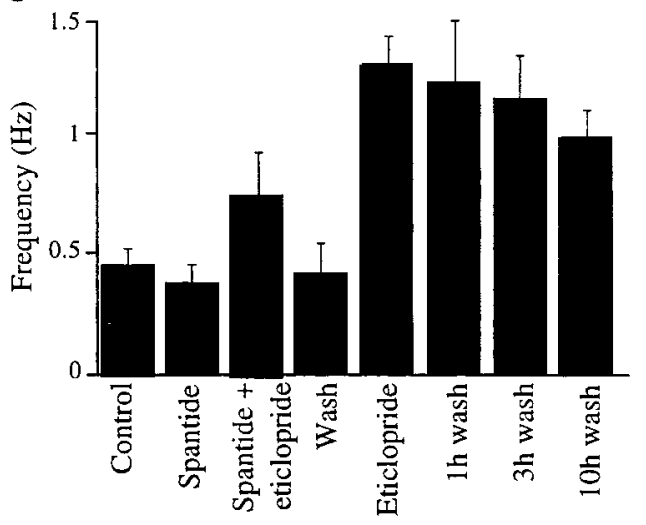

$\mathbf{B}$

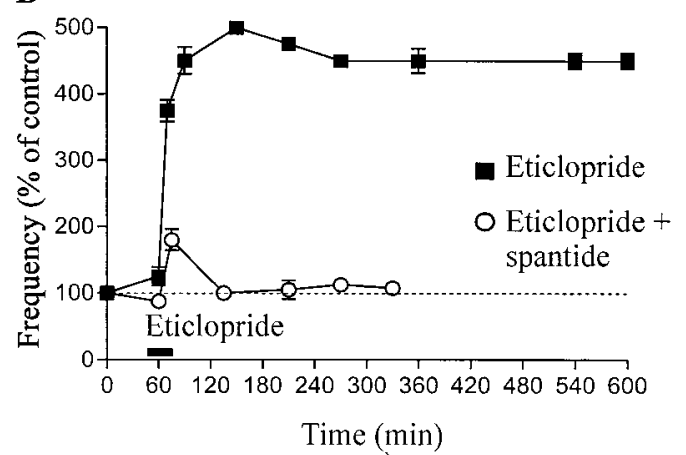

Figure 11. Bath application of the dopamine D2 receptor antagonist eticlopride $(20 \mu \mathrm{M})$ increased the frequency of ventral root bursts. $A$, Sample traces of ventral root activity. $B$, The effects of $20 \mu \mathrm{M}$ eticlopride did not recover after washing for $10 \mathrm{hr}$ and were blocked by the tachykinin antagonist spantide II $(4 \mu \mathrm{M})$. $C$, After wash-off of spantide, application of eticlopride again resulted in a prolonged increase in burst frequency.
D. Parker, unpublished observations). The synaptic potentiation is mediated presynaptically and postsynaptically, the postsynaptic effect being caused by the specific modulation of the NMDA component of the synaptic potential. The time course of the synaptic potentiation matches that of the potentiation of NMDA responses.

The maintenance phase of the burst frequency modulation, which begins $\sim 2-3 \mathrm{hr}$ after substance $\mathrm{P}$ application, was blocked by protein synthesis inhibitors. The protein synthesis inhibitor anisomycin was effective if given before or up to $1 \mathrm{hr}$ after substance $\mathrm{P}$ application. This is similar to the time window of effectiveness of anisomycin in blocking aversive learning in the chick (Freeman et al., 1995) and long-term facilitation in Aplysia (Bergold et al., 1990). Biochemical evidence showing that new protein synthesis occurs is required to confirm the role of protein synthesis. However, two results suggest that these inhibitors were not simply having toxic or nonspecific effects on the locomotor network. First, incubation in anisomycin for up to $7 \mathrm{hr}$ did not disrupt locomotor activity, and second, application of anisomycin for $1 \mathrm{hr}$ did not affect potentiated network activity when applied 2-4 hr after substance P.

Information is not yet available on what cellular and synaptic effects underlie the long-lasting protein synthesis-dependent phase of the network modulation. Substance P has several cellular and synaptic effects (Parker and Grillner, 1998; D. Parker, unpublished data), including the modulation of the membrane potential and excitability of network neurons and the presynaptic and postsynaptic potentiation of glutamatergic synaptic transmission. However, because these effects all recover after washing for $2 \mathrm{hr}$ at most, they cannot contribute directly to the maintained network modulation, but again could have a role in its induction or in the short-term effects of substance P.

One mechanism that has not been discussed is the role of non-NMDA receptors in the modulation of NMDA-evoked net- work activity. The maintenance of certain forms of hippocampal long-term potentiation rely on non-NMDA receptors after NMDA-dependent induction (Bliss and Collingridge, 1993). Locomotor activity in the lamprey has a low-frequency range (usually $0.05-3 \mathrm{~Hz}$ ) (Brodin et al., 1985), which has been reported to be mediated solely by NMDA receptor activation (Alford and Grillner, 1990), and a high-frequency range $(0.5-8 \mathrm{~Hz})$ that is elicited by kainate and AMPA receptor activation (Brodin et al., 1985). Because substance P potentiated the frequency of bursts elicited by low $(50 \mu \mathrm{M})$ NMDA into at least the high-frequency range for NMDA swimming (Fig. 1D), the involvement of nonNMDA receptors could be implicated in the potentiation of NMDA-evoked activity. Attempts to examine this were hampered by the disruption of NMDA-evoked locomotor activity after application of the non-NMDA receptor antagonists CNQX or NBQX (5-10 $\mu \mathrm{M} ; n=9$ of 14) (D. Parker, unpublished data). Two results, however, suggest against a role for non-NMDA receptors in the substance P-mediated modulation. First, substance $\mathrm{P}$ does not affect cellular responses to pressure-applied AMPA, and second, the potentiation of glutamatergic synaptic inputs is attributable to a specific effect on the NMDA component of the synaptic potential (D. Parker, unpublished data). Thus, there is as yet no evidence for a role of non-NMDA receptors in the network modulation.

\section{Role of the substance P-mediated network potentiation}

The DA/5-HT/TK-containing neurons are unpaired and form a dense bilateral plexus in which the dendrites of locomotor network neurons ramify. This bilateral plexus is thus well suited to influence the spinal locomotor network. Tachykinin release could have transient or prolonged effects, depending on the endogenous levels reached. Because the activity evoked in the isolated spinal cord resembles that in intact animals, this 
tachykinin release will result not only in faster swimming, but because of the modulation of the $\mathrm{CV}$ it will result in more regular burst activity and thus better "quality" swimming. Such changes may be important in adapting the motor pattern to different levels of activity, for example, when the animal changes from a sedentary to a migratory pattern of behavior (Hardisty and Potter, 1981).

\section{REFERENCES}

Adler EM, Augustine GJ, Duffy SN, Charlton MP (1991) Alien intracellular $\mathrm{Ca}^{2+}$ chelators attenuate neurotransmitter release at the squid giant synapse. J Neurosci 11:1496-1507.

Alford S, Grillner S (1990) CNQX and DNQX block non-NMDA synaptic transmission but not NMDA-evoked locomotion in lamprey spinal cord. Brain Res 506:297-302.

Barthe J-Y, Clarac F (1997) Modulation of the spinal network for locomotion by substance $\mathrm{P}$ in the neonatal rat. Exp Brain Res 115:485-492.

Ben Ari Y, Aniksztejn L, Bregestovski P (1992) Protein kinase C modulation of NMDA currents: an important link for LTP induction. Trends Neurosci 15:333-339.

Bliss TVP, Collingridge GL (1993) A synaptic model of memory: longterm potentiation in the hippocampus. Nature 361:31-39.

Bergold PJ, Sweatt JD, Winicov I, Weiss KR, Kandel ER, Schwartz JH (1990) Protein synthesis during acquisition of long-term facilitation is needed for the persistent loss of regulatory subunits of the Aplysia cAMP-dependent protein kinase. Proc Natl Acad Sci USA 87:3788-3791.

Brodin L, Grillner S (1985) The role of putative excitatory amino acid neurotransmitters in the initiation of locomotion in the lamprey spinal cord. 1. The effects of excitatory amino acid antagonists. Brain Res 360:139-148.

Brodin L, Grillner S (1986) Effects of magnesium on fictive locomotion induced by activation of $N$-methyl-D-aspartate (NMDA) receptors in the lamprey spinal cord in vitro. Brain Res 380:244-252.

Brodin L, Grillner S (1990) The lamprey CNS in vitro: an experimentally amenable model for synaptic transmission and integrative functions. In: Preparations of vertebrate central nervous system in vitro (Jahnsen H, ed), pp 103-153. New York: Wiley.

Brodin L, Grillner S, Rovainen C (1985) N-methyl-D-aspartate (NMDA), kainate and quisqualate receptors and the generation of fictive locomotion in the lamprey spinal cord. Brain Res 325:302-306.

Buchanan JT (1993) Electrophysiological properties of identified classes of lamprey spinal neurons. J Neurophysiol 70:2313-2325.

Buchanan JT (1996) Lamprey spinal interneurons and their roles in swimming activity. Brain Behav Evol 48:287-296.

Byrne JH, Kandel ER (1996) Presynaptic facilitation revisited: state and time-dependence. J Neurosci 16:425-435.

Chen L, Huang L-YM (1992) Protein kinase C reduces Mg2+ block of NMDA-receptor channels as a mechanism of modulation. Nature 356:521-523.

Dale N, Kandel ER, Schacher S (1987) Serotonin produces long-term changes in the excitability of Aplysia sensory neurons in culture that depend on protein synthesis. J Neurosci 7:2232-2238.

Duggan AW (1995) Release of neuropeptides in the spinal cord. Prog Brain Res 104:197-224.

El Manira A, Zhang W, Svensson E, Bussieres N (1997) 5-HT inhibits calcium current and synaptic transmission from sensory neurons in lamprey. J Neurosci 17:1786-1794.

Fazeli MS, Corbett J, Dunn MJ, Dolphin AC, Bliss TC (1993) Changes in protein synthesis accompanying long-term potentiation in the dentate gyrus in vivo. J Neurosci 13:1346-1353.

Freeman FM, Rose SPR, Scholey AB (1995) Two time windows of anisomycin-induced amnesia for passive avoidance training in the dayold chick. Neurobiol Learn Mem 63:291-295.

Gerber G, Kangrga I, Ryu, PD Larew A, Randic M (1992) Multiple effects of phorbol esters in the rat spinal dorsal horn. J Neurosci 9:3606-3617.

Greenberg SM, Castellucci VF, Bayley H, Schwartz JH (1987) A molecular mechanism for long-term sensitisation in Aplysia. Nature 329:62-65.

Grillner P, Hill RH, Grillner S (1991) 7-chlorokynurenic acid blocks NMDA receptor-induced fictive locomotion in lamprey-evidence for a physiological role of the glycine site. Acta Physiol Scand 141:131-132.
Grillner S, El Manira A, Tegnér J, Wadden T, Vinat L, Barthe J-Y (1994) Dynamic changes in functional connectivity in a lower vertebrate model. In: Cellular and molecular mechanisms underlying higher neural function (Selverston AJ, Asher P, eds), pp 127-147. New York: Wiley.

Grillner S, Deliagina T, Ekeberg Ö, El Manira A, Hill RH, Lansner A, Orlovsky GN, Wallén P (1995) Neuronal networks that co-ordinate locomotion and body orientation in lamprey. Trends Neurosci 18:270-279.

Hardisty MW, Potter IC (1981) The biology of lampreys. London: Academic.

Harris-Warrick RM, Cohen AH (1985) Serotonin modulates the central pattern generator for locomotion in the isolated lamprey spinal cord. J Exp Biol 116:27-46.

Harris-Warrick RM, Marder E, Selverston AI, Moulins M (1992) Dynamic biological networks. Cambridge, MA: MIT.

Hochner B, Parnas H, Parnas I (1991) Effects of intra-axonal injection of $\mathrm{Ca}^{2+}$ buffers on evoked release and on facilitation in the crayfish neuromuscular junction. Neurosci Lett 125:215-218.

Johnson JW, Ascher P (1986) Glycine potentiates the NMDA response of mouse central neurones. Nature 325:529-531.

Köhler C, Hall H, Gawell L (1986) Regional in vivo binding of the substituted benzamide $\left[{ }^{3} \mathrm{H}\right]$ eticlopride in the rat brain: evidence for selective labelling of dopamine receptors. Eur $\mathrm{J}$ Pharmacol 120:217-226.

Levine JD, Fields HL, Basbaum AI (1993) Peptides and the primary afferent nociceptor. J Neurosci 13:2273-2286.

Mayer ML, Westbrook G (1987) The physiology of excitatory amino acids in the vertebrate central nervous system. Prog Neurobiol 28:197-276.

Mayer ML, Westbrook GL, Guthrie AS (1984) Voltage dependent block by magnesium of NMDA responses in spinal cord neurones. Nature 309:261-263.

McClellan A, Grillner S (1984) Activation of fictive swimming by electrical stimulation of "locomotor regions" in the brainstem of the lamprey. Brain Res 300:357-361.

McPherson DR, Kemnitz CP (1994) Modulation of fictive swimming and motoneuron physiology by dopamine, and its immunocytochemical localization in the spinal cord. Neurosci Lett 166:23-26.

Montarolo PG, Goelet P, Castellucci VF, Morgan J, Kandel ER, Schacher S (1986) A critical period for macromolecular synthesis in long-term heterosynaptic facilitation in Aplysia. Science 234:1249-1254.

Ouanounou A, Zhang L, Tymianski M, Charlton MP, Wallace MC, Carlen PL (1996) Accumulation and extrusion of permeant $\mathrm{Ca}^{2+}$ chelators in attenuation of synaptic transmission at hippocampal CA1 neurons. Neuroscience 75:99-109.

Parker DJ, Grillner S (1996) Tachykinin-mediated modulation of sensory neurons, interneurons, and synaptic transmission in the lamprey spinal cord. J Neurophysiol 76:4031-4039.

Parker DJ, Grillner S (1998) Long-term modulation of spinal locomotor circuits in the lamprey. Göttingen Neurobiology Meeting abstract, March, 1998.

Parker DJ, Svensson E, Grillner S (1997) Substance P modulates mechanosensory afferents in the lamprey via a protein kinase $\mathrm{C}$-mediated reduction of potassium conductances. Eur J Neurosci 9:2064-2076.

Rose SPR (1991) How chicks make memories: the cellular cascade from c-fos to dendritic remodelling. Trends Neurosci 14:390-397.

Rusin KI, Ryu PD, Randic M (1992) Modulation of excitatory amino acid responses in rat dorsal horn neurons by tachykinins. J Neurophysiol 68:265-286.

Schotland J, Shupliakov O, Wikström M, Brodin L, Srinivasan M, You Z, Herrera-Marschitz M, Zhang W, Hökfelt T, Grillner S (1995) Control of lamprey locomotor neurons by colocalized monoamine transmitters. Nature 374:266-268.

Schotland JL, Shupliakov O, Grillner S, Brodin L (1996) synaptic and non-synaptic monoaminergic neuron systems in the lamprey spinal cord. J Comp Neurol 372:229-244.

Thomas KL, Laroche S, Errington ML, Bliss TVP, Hunt SP (1994) Spatial and temporal changes in signal transduction pathways during LTP. Neuron 13:737-745.

Van Dongen P, Hokfelt T, Grillner S, Verhofsted AAJ, Steinbush HWM, Cuello AC, Terenius L (1985) Immunohistochemical demonstration of some putative neurotransmitters in the lamprey spinal cord and 
spinal ganglia: 5-hydroxytryptamine, tachykinin, and neuropeptide $\mathrm{Y}$ immunoreactive neurons and fibers. J Comp Neurol 234:501-522.

Van Dongen P, Theodorsson-Norheim E, Brodin E, Hökfelt T, Grillner S, Peters A, Cuello AC, Forssman WG, Reinecke M, Singer EA, Lazarus LH (1986) Immunohistochemical and chromatographic studies of peptides with tachykinin-like immunoreactivity in the central nervous system of the lamprey. Peptides 7:297-313.

Wallén P, Grillner S (1987) N-methyl-D-aspartate receptor-induced inherent oscillatory activity in neurons active during locomotion in the lamprey. J Neurosci 7:2745-2755.

Wallén P, Buchanan JT, Grillner S, Hill RH, Christenson J, Hokfelt T (1989) Effects of 5-hydroxytryptamine on the afterhyperpolarisation, spike frequency regulation and oscillatory membrane properties in lamprey spinal cord nerves. J Neurophysiol 61:759-768.

Waugh D, Bondareva V, Rusakov, Bjenning CY, Nielson PF, Conlon JM (1995) Tachykinins with unusual structural features from a urodele, the amphiuma, an elasmobranch, the hammerhead shark, and an agnathan, the river lamprey. Peptides 16:615-621.

White SR (1985) A comparison of the effects of serotonin, substance P, and thyrotrophin releasing hormone on the excitability of rat spinal motor neurones in vivo. Brain Res 335:63-70.

Yanagisawa M, Hosaki R, Otsuka M (1992) The isolated spinal cordskin preparation of the newborn rat and the effects of some allogenic and analgesic substances. Eur J Pharmacol 220:111-117. 